\title{
French, German, and Japanese FDI on Intra-East Asian Trade
}

\author{
K.C. Fung \\ University of California, Santa Cruz, U. S. A. \\ Nathalie Aminian \\ University of Rouen, Rouen, France \\ Alicia Garcia-Herrero \\ Emerging Markets, BBVA, Rouen, Hong Kong \\ Hitomi Iizaka \\ Aoyama Gakuin University, Tokyo, Japan \\ Francis $\mathrm{Ng}$ \\ World Bank, Washington DC, U. S. A.
}

\begin{abstract}
In this paper we first document the growing importance of intra-East Asian trade in parts and components and capital goods facilitated by foreign direct investment (FDI). Japanese direct investment has a stronger influence on intra-East Asian trade relative to FDI from France and Germany. It is related to the roles of small and medium enterprises in the Japanese FDI in East and Southeast Asia.
\end{abstract}

JEL Classifications: F14, F15, F23

Key Words: French FDI, German FDI, Japanese FDI, East and Southeast Asian Trade

\footnotetext{
* Corresponding Author: K.C. Fung; Department of Economics, University of California, Santa Cruz, CA 95064, U. S. A.; E-mail: kcfung@ ucsc.edu.

Co-Author: Nathalie Aminian; Department of Economics, University of Rouen, 3, avenue Pasteur 76186 Rouen Cedex, France; Tel: +33 (0)232769534, Fax: +33 (0)232769881, E-mail: nathalie.aminian@univ-rouen.fr;

Alicia Garcia-Herrero; Emerging Markets, BBVA, BBVA Hong Kong Branch 10/F., Two International Finance Centre 8 Finance Street Central, Hong Kong; E-mail: alicia.garcia- herrero@bbva.com.hk;

Hitomi Iizaka; Department of International Economics, Aoyama Gakuin University, School of International Politics, Economics and Communication, 4-4-25 Shibuya, Shibuya-ku, Tokyo 150-8366, Japan; E-mail: iizaka@sbcglobal.net;

Francis Ng; Development Research Group-International Trade and Integration, The World Bank, 1818 H Street, NW, MC3303, Washington DC 20433, U. S. A.; Tel: +1 2024738088, Fax: +12025221159, E-mail: fng@worldbank.org.
} 


\section{Introduction}

East Asia ${ }^{1}$ has witnessed a remarkable increase in the volume of intraregional trade during the past two decades. In particular, many countries in the region have experienced the explosive growth in intra-regional trade in parts and components. An important development that has contributed to the phenomena has been identified as the international fragmentation of production where the production process of a final product is split into two or more steps and each production stage is undertaken in different locations across national boundaries. Many alternative names have been coined for such a phenomenon, including "slicing the value chain" (Krugman, 1995), "vertical specialization" (Hummels, Ishii, and Yi, 2001), "international production sharing" (Ng and Yeats, 2001) and "outsourcing" (Hanson et al., 2001).

Growing evidence documents the phenomenal increase in the international fragmentation of production in a variety of industries such as textiles and apparel, machinery and transport equipment, consumer electronics, toys and furniture. The extent of international production fragmentation and the depth of the regional production networks, however, vary according to industries. As Hiratsuka (2008) points out, the international production fragmentation in industries such as textiles involves relatively simple disintegration of procurement and production. In contrast, more elaborate and well-developed production network is found in the electronics industry.

It is often hypothesized that Multinational Enterprises (MNEs) are the driving force behind the development of fragmentation process. The international fragmentation of production will be adopted if it is a cost-saving strategy for MNEs. By doing so, they combine many resources available at different locations across national borders leading to establishing their production networks. The standard comparative advantage in trade theory predicts that the firms locate relatively labor-intensive segment of the production in the country where labor is abundant whereas locate relatively capital-intensive segment of the production in the country where capital is abundant, that is driven by factor-endowment dissimilarities. In East and Southeast Asia, the rapid growth of intra-regional trade has also been associated with a rising volume of Foreign Direct Investment (FDI). As a result, East Asia (excluding Japan) has gained in importance as recipients of FDI over time. Recent improvements in service links in terms of lower transportation and communications costs as well as the progressive liberalization and deregulation of international trade and foreign direct investment in the region, also contributed to this trend. Furthermore, the dispersed production networks created by such fragmentation appear to be more extensive in East Asia than in any other parts of the world (Fung, Garcia-Herrero and Siu 2009; Athukorala, 2006; Ng and Yeats, 2001; 2003). The expansion of trade and intra-

\footnotetext{
${ }^{1}$ In this study, East Asia covers the following countries/regions: China, Hong Kong, Japan, Republic of Korea, Indonesia, the Philippines, Malaysia, Singapore, and Thailand.
} 
regional trade have also raised the growth rates of various Asian economies (Zhang 2001).

International production fragmentation and the formation of regional production networks can have various important implications for international trade. When MNEs engage in production fragmentation, initially, production may be geographically fragmented across national boundaries but organizationally confined within the boundaries of a transnational firm. Affiliates of MNEs may rely heavily on imported intermediate products from their home countries if they are faced with limited choices of local suppliers of those products. This will be the case if intermediate inputs require specialized production techniques that are not yet available in the host countries. It is widely recognized that a significant amount of trade in the global economy is indeed carried out in the form of intra-firm trade, which may be reflection of FDI-based production fragmentation. Moreover, as production is fragmented across locations, exports of capital goods required to produce parts and components from an FDI source country may also expand. It may also increase imports by an FDI source country as a host country increases exports of finished products back to the source country.

These networks, over time, disseminate knowledge to local suppliers in the host countries, which can then enhance local capability formation (Ernst, 2000). Advanced knowledge possessed by the MNEs may be spilled over through contractual relationship with local firms. Production linkages as well as procurement relationships between the foreign affiliates and the domestic firms are likely to be created and local technological capability for producing intermediate goods improves. Furthermore, against the backdrop of intensified competition in the world market in many industries, MNEs have been under pressure to reduce their costs of sourcing intermediate products instead of focusing on the origin of the suppliers. Regional production networks then cover both intra-firm and inter-firm transactions linking together affiliates, joint ventures with its subcontractors, suppliers as well as service providers. When foreign affiliates start sourcing intermediate goods locally, it will partially offset the tradecreating effect of FDI.

At the same time, industry agglomeration or clusters may form networks involving affiliates and non-affiliates for intermediate products when economies of scale create more profits to offset transportation costs. Countries then tend to specialize more narrowly within industries to define their own niche markets and achieve scale economies. Take the hard disk drive industry in Thailand for instance. Parts and components are procured locally as well as from other countries in Asia. Furthermore, several suppliers located in different countries supply the same parts and components to several assemblers on behalf of Seagate, Western Digital, Hitachi, Fujitsu (Hiratsuka 2008). Evidence of industrial clusters can be found in various parts of East Asia; examples include the Shanghai-Jiangsu corridor and Guangzhou in China, the Eastern Seaboard in Thailand, Penang in Malaysia and parts of Hsingchu and Taoyuang in Taiwan. The industrial clusters subsequently led to the expansion of the international exchange of parts and components and capital goods within East Asia.

Antras (2005) proposes a theory of incomplete contracts that suggests that production 
fragmentation will go through several stages. First, parts and components will be produced within a single country where the firm is located. Second, attracted by lower wages in the developing countries and facilitated by the standardization of the production the multinational firms will seek to outsource some of the lower end production activities. The constraining factor is the institutional weakness, particularly intellectual property rights protection in emerging economies. Thus the first stage of transnational production sharing is intra-firm - using foreign direct investment and foreign affiliates to protect the technology and skill content contained in these components. The next stage of offshoring is to localize the fragmentation process by subcontracting with the local firms. The last stage consists of the entire process being produced overseas, with only marketing, research and development, and other managerial functions being retained in the home country. Then, where is East Asia situated in the product cycle of offshoring today? Does foreign direct investment play an important role? Is it really true that foreign direct investment systematically facilitate trade in parts and components, particularly in East Asia?

Furthermore, does the nationality or the source of investment make a difference in this regard? Production networks may be coordinated in a variety of ways involving a mix of intrafirm and inter-firm structures. It has been documented that there exists significant differences in the nature of the production networks created by MNEs from different countries. One defining characteristics of the structures of Japanese production network is that they are hierarchical networks (Sturgeon 2003). In other words, dominant leadin firms effectively coordinate tiers of suppliers. Japanese networks had been structured based on long-term business and traditional keiretsu relationships, and thus relatively closed to outsiders (Borrus et al., 2000, Fung 2002). The suppliers are 'captive' in a sense that they can't switch buyers of their products easily due to relation-specific investment and asset specificity. Leading firms at the same time make exit an unattractive option for their suppliers by providing enough resources and market access (Gereffi et al., 2005). This type of production networks exhibit a lower propensity to engage in external sourcing.

As Japanese manufacturers have expanded into Asia, they have tried to replicate their homegrown vertical keiretsu system. For example, electrical industries as well as automobile ones consist of layers of subcontractors in Japan. Small and Medium Enterprises (SMEs), as subcontractors to larger multinationals, function as suppliers of intermediate goods. After large-scaled Japanese manufacturers shifted their production site from Japan to various Asian countries seeking low-cost assembly sites for labor-intensive production processes in 1970s and 1980s, SMEs also established their overseas production to extend the long-term close business ties. A large part of FDI by Japanese MNEs is actually undertaken by SMEs, which is a distinctive characteristic of Japanese FDI. Those SMEs which produce parts and machinery for the large manufacturers also established production networks in the East Asian countries.

Although identifying any systematic differences in trade and FDI behaviors between of Japanese and European firms is beyond the scope of this paper, we will simply examine whether FDI from those countries could have different implications on intra-regional trade in East Asia. 


\section{Patterns of Trade in East Asia}

\section{A. Intra-regional trade}

Table $1 \mathrm{a}$ and $1 \mathrm{~b}$ examine the changes in the share of geographic direction of individual East Asian $^{2}$ imports and exports, respectively for 1985, 1995, 2003, 2006 and 2009. These Tables also include the figures for North America and EU15 for comparisons.

East Asia in general appears to have gone through significant changes in the direction of their imports. Intra-East Asian trade already commanded a large share of their total trade in 1985 at $48.7 \%$, and then continued to grow to $60.8 \%$ and 59.6\% in 2003 and 2006, respectively. The increase is largely attributed to China. China's share almost tripled from $5.9 \%$ to $16.3 \%$ between 1985 and 2006. However, the share of intra-Asian trade declined from 59.6\% in 2006 to $55.8 \%$ in 2009 , alongside with the deepening global downturn. A large part of intra-East Asian trade is linked to the international production networks which produce finished goods that are then shipped to major importing countries. As the global financial crisis deepened since 2008, the share of intra-East Asian trade which considerably depends on demand, from developed economies, may also have declined.

Table 1a. The Geographic Pattern of East Asian Imports

\begin{tabular}{|c|c|c|c|c|c|c|c|c|}
\hline \multicolumn{2}{|c|}{ importing country } & \multirow{2}{*}{$\begin{array}{r}\text { East Asia } \\
48.7 \%\end{array}$} & \multirow{2}{*}{$\frac{\text { Japan }}{25.7 \%}$} & \multirow{2}{*}{$\frac{\text { China }}{5.9 \%}$} & \multirow{2}{*}{$\frac{\text { NIEs }}{10.7 \%}$} & \multirow{2}{*}{$\begin{array}{r}\text { ASEAN4 } \\
6.4 \%\end{array}$} & \multirow{2}{*}{$\begin{array}{c}\begin{array}{c}\text { North } \\
\text { America }\end{array} \\
17.1 \%\end{array}$} & \multirow{2}{*}{$\begin{array}{r}\text { EU15 } \\
13.6 \%\end{array}$} \\
\hline East Asia & 1985 & & & & & & & \\
\hline & 1995 & $56.4 \%$ & $22.8 \%$ & $10.0 \%$ & $16.0 \%$ & $7.5 \%$ & $15.8 \%$ & $13.9 \%$ \\
\hline & 2003 & $60.8 \%$ & $17.5 \%$ & $14.3 \%$ & $18.4 \%$ & $10.7 \%$ & $11.3 \%$ & $11.0 \%$ \\
\hline & 2006 & $59.6 \%$ & $14.4 \%$ & $16.3 \%$ & $18.4 \%$ & $10.4 \%$ & $9.6 \%$ & $9.8 \%$ \\
\hline & 2009 & $55.8 \%$ & $12.9 \%$ & $16.1 \%$ & $16.7 \%$ & $10.1 \%$ & $9.1 \%$ & $10.5 \%$ \\
\hline \multirow[t]{5}{*}{ Japan } & 1985 & $25.9 \%$ & & $5.1 \%$ & $7.7 \%$ & $13.1 \%$ & $24.0 \%$ & $7.6 \%$ \\
\hline & 1995 & $34.7 \%$ & & $10.8 \%$ & $12.3 \%$ & $11.5 \%$ & $25.9 \%$ & $14.5 \%$ \\
\hline & 2003 & $42.4 \%$ & & $19.7 \%$ & $10.2 \%$ & $12.5 \%$ & $17.6 \%$ & $12.8 \%$ \\
\hline & 2006 & $41.4 \%$ & & $20.5 \%$ & $9.8 \%$ & $11.1 \%$ & $13.7 \%$ & $10.0 \%$ \\
\hline & 2009 & $41.9 \%$ & & $22.3 \%$ & $8.6 \%$ & $11.0 \%$ & $12.6 \%$ & $10.3 \%$ \\
\hline \multirow[t]{5}{*}{ Korea } & 1985 & $34.8 \%$ & $24.2 \%$ & $0.0 \%$ & $3.5 \%$ & $7.1 \%$ & $22.8 \%$ & $11.0 \%$ \\
\hline & 1995 & $40.0 \%$ & $24.6 \%$ & $5.6 \%$ & $4.2 \%$ & $5.6 \%$ & $24.7 \%$ & $13.4 \%$ \\
\hline & 2003 & $47.1 \%$ & $20.3 \%$ & $12.3 \%$ & $7.1 \%$ & $7.5 \%$ & $15.0 \%$ & $10.8 \%$ \\
\hline & 2006 & $45.0 \%$ & $16.8 \%$ & $15.7 \%$ & $5.6 \%$ & $7.0 \%$ & $11.9 \%$ & $9.4 \%$ \\
\hline & 2009 & $45.1 \%$ & $15.3 \%$ & $16.8 \%$ & $5.9 \%$ & $7.0 \%$ & $10.1 \%$ & $9.5 \%$ \\
\hline
\end{tabular}

\footnotetext{
As defined in Table 1, in this chapter East Asia includes China, Hong Kong, China, Indonesia, Japan, Republic of Korea, Malaysia, Philippines, Singapore, Taiwan Province of China and Thailand.
} 


\begin{tabular}{|c|c|c|c|c|c|c|c|c|}
\hline \multirow[t]{5}{*}{ Taiwan } & 1985 & $37.1 \%$ & $27.6 \%$ & $0.0 \%$ & $3.8 \%$ & $5.7 \%$ & $25.5 \%$ & $11.1 \%$ \\
\hline & 1995 & $48.0 \%$ & $29.2 \%$ & $3.0 \%$ & $8.8 \%$ & $7.0 \%$ & $21.6 \%$ & $14.4 \%$ \\
\hline & 2003 & $56.1 \%$ & $25.7 \%$ & $8.7 \%$ & $11.4 \%$ & $10.3 \%$ & $14.2 \%$ & $10.4 \%$ \\
\hline & 2006 & $54.8 \%$ & $23.0 \%$ & $12.3 \%$ & $10.9 \%$ & $8.6 \%$ & $11.9 \%$ & $8.6 \%$ \\
\hline & 2009 & $52.3 \%$ & $20.8 \%$ & $14.0 \%$ & $9.4 \%$ & $8.0 \%$ & $11.1 \%$ & $8.7 \%$ \\
\hline \multirow{5}{*}{$\begin{array}{l}\text { Hong } \\
\text { Kong }\end{array}$} & 1985 & $68.8 \%$ & $23.1 \%$ & $25.5 \%$ & $17.5 \%$ & $2.8 \%$ & $9.8 \%$ & $12.3 \%$ \\
\hline & 1995 & $74.5 \%$ & $14.8 \%$ & $36.2 \%$ & $18.8 \%$ & $4.6 \%$ & $8.4 \%$ & $10.8 \%$ \\
\hline & 2003 & $78.9 \%$ & $11.8 \%$ & $43.3 \%$ & $17.1 \%$ & $6.6 \%$ & $5.9 \%$ & $8.3 \%$ \\
\hline & 2006 & $81.1 \%$ & $10.3 \%$ & $45.8 \%$ & $18.4 \%$ & $6.6 \%$ & $5.2 \%$ & $7.1 \%$ \\
\hline & 2009 & $78.5 \%$ & $9.2 \%$ & $45.7 \%$ & $15.7 \%$ & $7.8 \%$ & $5.2 \%$ & $7.6 \%$ \\
\hline \multirow[t]{5}{*}{ Singapore } & 1985 & $49.6 \%$ & $17.0 \%$ & $8.6 \%$ & $6.8 \%$ & $17.2 \%$ & $15.5 \%$ & $12.2 \%$ \\
\hline & 1995 & $57.6 \%$ & $21.1 \%$ & $3.3 \%$ & $11.8 \%$ & $21.5 \%$ & $15.5 \%$ & $13.4 \%$ \\
\hline & 2003 & $58.1 \%$ & $11.3 \%$ & $8.1 \%$ & $10.7 \%$ & $28.0 \%$ & $13.6 \%$ & $11.7 \%$ \\
\hline & 2006 & $57.5 \%$ & $8.3 \%$ & $11.4 \%$ & $12.5 \%$ & $25.3 \%$ & $13.1 \%$ & $10.9 \%$ \\
\hline & 2009 & $53.2 \%$ & $7.6 \%$ & $10.5 \%$ & $12.2 \%$ & $22.8 \%$ & $12.3 \%$ & $13.1 \%$ \\
\hline \multirow[t]{5}{*}{ China } & 1985 & $49.8 \%$ & $35.8 \%$ & & $11.9 \%$ & $2.1 \%$ & $14.6 \%$ & $16.5 \%$ \\
\hline & 1995 & $54.6 \%$ & $22.0 \%$ & & $28.1 \%$ & $4.5 \%$ & $14.2 \%$ & $16.1 \%$ \\
\hline & 2003 & $54.1 \%$ & $18.0 \%$ & & $27.6 \%$ & $8.4 \%$ & $9.3 \%$ & $12.8 \%$ \\
\hline & 2006 & $49.3 \%$ & $14.6 \%$ & & $25.9 \%$ & $8.7 \%$ & $8.5 \%$ & $11.0 \%$ \\
\hline & 2009 & $42.5 \%$ & $13.0 \%$ & & $21.3 \%$ & $8.2 \%$ & $8.9 \%$ & $12.0 \%$ \\
\hline \multirow[t]{5}{*}{ Thailand } & 1985 & $49.9 \%$ & $26.5 \%$ & $2.4 \%$ & $13.7 \%$ & $7.2 \%$ & $12.6 \%$ & $16.1 \%$ \\
\hline & 1995 & $55.4 \%$ & $30.7 \%$ & $3.0 \%$ & $15.3 \%$ & $6.4 \%$ & $12.7 \%$ & $15.9 \%$ \\
\hline & 2003 & $57.5 \%$ & $24.1 \%$ & $8.0 \%$ & $13.8 \%$ & $11.6 \%$ & $10.0 \%$ & $10.0 \%$ \\
\hline & 2006 & $56.4 \%$ & $20.1 \%$ & $10.6 \%$ & $13.6 \%$ & $12.1 \%$ & $7.1 \%$ & $8.4 \%$ \\
\hline & 2009 & $56.7 \%$ & $18.7 \%$ & $12.7 \%$ & $13.2 \%$ & $12.1 \%$ & $6.8 \%$ & $8.8 \%$ \\
\hline \multirow[t]{5}{*}{ Malaysia } & 1985 & $54.2 \%$ & $23.2 \%$ & $2.1 \%$ & $22.4 \%$ & $6.6 \%$ & $16.4 \%$ & $16.1 \%$ \\
\hline & 1995 & $59.1 \%$ & $28.1 \%$ & $2.3 \%$ & $23.7 \%$ & $5.0 \%$ & $17.1 \%$ & $15.6 \%$ \\
\hline & 2003 & $63.1 \%$ & $17.2 \%$ & $8.8 \%$ & $25.1 \%$ & $12.0 \%$ & $16.0 \%$ & $11.8 \%$ \\
\hline & 2006 & $63.0 \%$ & $13.2 \%$ & $12.1 \%$ & $25.2 \%$ & $12.5 \%$ & $13.0 \%$ & $11.1 \%$ \\
\hline & 2009 & $60.9 \%$ & $12.4 \%$ & $13.9 \%$ & $22.3 \%$ & $12.2 \%$ & $11.7 \%$ & $11.4 \%$ \\
\hline \multirow[t]{5}{*}{ Indonesia } & 1985 & $45.0 \%$ & $14.4 \%$ & $5.4 \%$ & $13.7 \%$ & $11.5 \%$ & $25.9 \%$ & $9.3 \%$ \\
\hline & 1995 & $51.4 \%$ & $22.1 \%$ & $2.3 \%$ & $21.0 \%$ & $5.9 \%$ & $19.9 \%$ & $10.7 \%$ \\
\hline & 2003 & $53.1 \%$ & $13.0 \%$ & $9.1 \%$ & $20.8 \%$ & $10.2 \%$ & $9.3 \%$ & $10.9 \%$ \\
\hline & 2006 & $55.0 \%$ & $9.0 \%$ & $10.9 \%$ & $23.9 \%$ & $11.3 \%$ & $7.8 \%$ & $9.7 \%$ \\
\hline & 2009 & $61.0 \%$ & $10.2 \%$ & $14.5 \%$ & $25.2 \%$ & $11.2 \%$ & $8.4 \%$ & $8.6 \%$ \\
\hline \multirow[t]{5}{*}{ Philippines } & 1985 & $42.9 \%$ & $25.8 \%$ & $2.4 \%$ & $13.5 \%$ & $1.2 \%$ & $18.7 \%$ & $19.0 \%$ \\
\hline & 1995 & $47.3 \%$ & $22.7 \%$ & $3.7 \%$ & $17.0 \%$ & $3.9 \%$ & $13.7 \%$ & $20.1 \%$ \\
\hline & 2003 & $55.0 \%$ & $19.5 \%$ & $4.6 \%$ & $21.5 \%$ & $9.4 \%$ & $22.4 \%$ & $8.1 \%$ \\
\hline & 2006 & $57.6 \%$ & $14.2 \%$ & $7.2 \%$ & $26.2 \%$ & $10.0 \%$ & $16.6 \%$ & $8.3 \%$ \\
\hline & 2009 & $60.9 \%$ & $12.6 \%$ & $8.9 \%$ & $25.8 \%$ & $13.7 \%$ & $12.5 \%$ & $7.2 \%$ \\
\hline \multirow{5}{*}{$\begin{array}{l}\text { North } \\
\text { America }\end{array}$} & 1985 & $31.6 \%$ & $17.7 \%$ & $1.0 \%$ & $10.2 \%$ & $2.7 \%$ & $27.9 \%$ & $19.9 \%$ \\
\hline & 1995 & $35.0 \%$ & $14.6 \%$ & $5.6 \%$ & $9.8 \%$ & $5.1 \%$ & $27.5 \%$ & $16.4 \%$ \\
\hline & 2003 & $31.0 \%$ & $8.5 \%$ & $11.4 \%$ & $6.8 \%$ & $4.4 \%$ & $24.3 \%$ & $18.1 \%$ \\
\hline & 2006 & $31.7 \%$ & $7.3 \%$ & $14.8 \%$ & $5.5 \%$ & $4.1 \%$ & $22.2 \%$ & $16.3 \%$ \\
\hline & 2009 & $32.4 \%$ & $5.7 \%$ & $18.0 \%$ & $5.1 \%$ & $3.6 \%$ & $20.6 \%$ & $16.4 \%$ \\
\hline \multirow[t]{5}{*}{$E U 15$} & 1985 & $6.5 \%$ & $3.5 \%$ & $0.4 \%$ & $1.7 \%$ & $0.9 \%$ & $8.4 \%$ & $56.2 \%$ \\
\hline & 1995 & $10.4 \%$ & $4.1 \%$ & $1.7 \%$ & $3.0 \%$ & $1.6 \%$ & $8.1 \%$ & $61.5 \%$ \\
\hline & 2003 & $11.4 \%$ & $3.1 \%$ & $4.1 \%$ & $2.5 \%$ & $1.8 \%$ & $7.2 \%$ & $58.5 \%$ \\
\hline & 2006 & $12.2 \%$ & $2.4 \%$ & $5.7 \%$ & $2.5 \%$ & $1.5 \%$ & $6.4 \%$ & $53.9 \%$ \\
\hline & 2009 & $13.0 \%$ & $2.1 \%$ & $7.1 \%$ & $2.3 \%$ & $1.5 \%$ & $6.6 \%$ & $53.1 \%$ \\
\hline
\end{tabular}

(Source) Compiled from UN Comtrade data base, Author's calculation 
Table 1b. The Geographic Pattern of East Asian Exports

\begin{tabular}{|c|c|c|c|c|c|c|c|c|}
\hline \multicolumn{2}{|c|}{ exporting country to } & East Asia & Japan & China & NIEs & ASEAN4 & $\begin{array}{c}\text { North } \\
\text { America }\end{array}$ & EU15 \\
\hline \multirow[t]{5}{*}{ East Asia } & 1985 & $42.4 \%$ & $16.9 \%$ & $4.7 \%$ & $15.1 \%$ & $5.7 \%$ & $29.4 \%$ & $11.4 \%$ \\
\hline & 1995 & $51.0 \%$ & $12.9 \%$ & $8.7 \%$ & $20.9 \%$ & $8.4 \%$ & $21.1 \%$ & $13.9 \%$ \\
\hline & 2003 & $51.6 \%$ & $10.6 \%$ & $12.6 \%$ & $20.1 \%$ & $8.3 \%$ & $19.4 \%$ & $14.2 \%$ \\
\hline & 2006 & $49.6 \%$ & $8.9 \%$ & $13.1 \%$ & $19.7 \%$ & $7.9 \%$ & $17.9 \%$ & $14.2 \%$ \\
\hline & 2009 & $47.4 \%$ & $7.6 \%$ & $13.5 \%$ & $18.6 \%$ & $7.8 \%$ & $14.8 \%$ & $13.4 \%$ \\
\hline \multirow[t]{5}{*}{ Japan } & 1985 & $24.1 \%$ & & $7.1 \%$ & $12.8 \%$ & $4.2 \%$ & $40.2 \%$ & $13.2 \%$ \\
\hline & 1995 & $42.0 \%$ & & $5.0 \%$ & $25.0 \%$ & $12.1 \%$ & $28.9 \%$ & $15.9 \%$ \\
\hline & 2003 & $44.9 \%$ & & $12.2 \%$ & $23.5 \%$ & $9.2 \%$ & $26.5 \%$ & $15.3 \%$ \\
\hline & 2006 & $45.7 \%$ & & $14.3 \%$ & $23.2 \%$ & $8.1 \%$ & $24.3 \%$ & $13.6 \%$ \\
\hline & 2009 & $51.5 \%$ & & $18.9 \%$ & $23.5 \%$ & $9.1 \%$ & $17.7 \%$ & $11.4 \%$ \\
\hline \multirow[t]{5}{*}{ Korea } & 1985 & $25.8 \%$ & $15.0 \%$ & $0.0 \%$ & $7.4 \%$ & $3.4 \%$ & $39.7 \%$ & $11.7 \%$ \\
\hline & 1995 & $44.8 \%$ & $13.7 \%$ & $7.5 \%$ & $15.9 \%$ & $7.7 \%$ & $21.3 \%$ & $13.3 \%$ \\
\hline & 2003 & $47.2 \%$ & $8.9 \%$ & $18.1 \%$ & $13.6 \%$ & $6.6 \%$ & $19.2 \%$ & $12.9 \%$ \\
\hline & 2006 & $47.8 \%$ & $8.2 \%$ & $21.3 \%$ & $12.7 \%$ & $5.6 \%$ & $14.8 \%$ & $12.5 \%$ \\
\hline & 2009 & $46.9 \%$ & $6.0 \%$ & $23.8 \%$ & $11.8 \%$ & $5.3 \%$ & $11.3 \%$ & $9.1 \%$ \\
\hline \multirow[t]{5}{*}{ Taiwan } & 1985 & $26.4 \%$ & $11.3 \%$ & $0.0 \%$ & $12.0 \%$ & $3.1 \%$ & $51.4 \%$ & $9.4 \%$ \\
\hline & 1995 & $50.2 \%$ & $11.8 \%$ & $0.3 \%$ & $29.6 \%$ & $8.5 \%$ & $25.0 \%$ & $13.1 \%$ \\
\hline & 2003 & $59.7 \%$ & $8.6 \%$ & $15.9 \%$ & $28.3 \%$ & $6.8 \%$ & $19.4 \%$ & $13.1 \%$ \\
\hline & 2006 & $64.9 \%$ & $7.6 \%$ & $24.3 \%$ & $25.2 \%$ & $7.7 \%$ & $16.0 \%$ & $10.4 \%$ \\
\hline & 2009 & $63.7 \%$ & $7.1 \%$ & $26.6 \%$ & $22.3 \%$ & $7.6 \%$ & $12.3 \%$ & $9.5 \%$ \\
\hline \multirow{5}{*}{$\begin{array}{l}\text { Hong } \\
\text { Kong }\end{array}$} & 1985 & $40.8 \%$ & $4.2 \%$ & $26.0 \%$ & $7.0 \%$ & $3.6 \%$ & $33.2 \%$ & $13.6 \%$ \\
\hline & 1995 & $50.1 \%$ & $6.1 \%$ & $33.3 \%$ & $7.1 \%$ & $3.6 \%$ & $23.3 \%$ & $15.0 \%$ \\
\hline & 2003 & $57.4 \%$ & $5.3 \%$ & $41.7 \%$ & $7.0 \%$ & $3.4 \%$ & $19.5 \%$ & $13.7 \%$ \\
\hline & 2006 & $60.6 \%$ & $4.8 \%$ & $46.3 \%$ & $6.2 \%$ & $3.2 \%$ & $15.9 \%$ & $13.7 \%$ \\
\hline & 2009 & $63.2 \%$ & $4.3 \%$ & $49.8 \%$ & $5.9 \%$ & $3.2 \%$ & $12.1 \%$ & $12.8 \%$ \\
\hline \multirow[t]{5}{*}{ Singapore } & 1985 & $40.7 \%$ & $9.4 \%$ & $1.5 \%$ & $9.3 \%$ & $20.6 \%$ & $21.9 \%$ & $11.0 \%$ \\
\hline & 1995 & $52.0 \%$ & $7.8 \%$ & $2.3 \%$ & $15.4 \%$ & $26.5 \%$ & $18.8 \%$ & $13.4 \%$ \\
\hline & 2003 & $59.5 \%$ & $6.1 \%$ & $6.3 \%$ & $17.1 \%$ & $30.0 \%$ & $13.1 \%$ & $12.1 \%$ \\
\hline & 2006 & $60.2 \%$ & $5.5 \%$ & $9.7 \%$ & $16.7 \%$ & $28.2 \%$ & $10.5 \%$ & $10.6 \%$ \\
\hline & 2009 & $60.5 \%$ & $4.5 \%$ & $9.7 \%$ & $19.5 \%$ & $26.7 \%$ & $7.5 \%$ & $8.7 \%$ \\
\hline \multirow[t]{5}{*}{ China } & 1985 & $58.6 \%$ & $22.2 \%$ & & $33.7 \%$ & $2.7 \%$ & $9.4 \%$ & $9.2 \%$ \\
\hline & 1995 & $55.9 \%$ & $19.1 \%$ & & $33.1 \%$ & $3.7 \%$ & $17.7 \%$ & $12.9 \%$ \\
\hline & 2003 & $43.6 \%$ & $13.6 \%$ & & $26.1 \%$ & $4.0 \%$ & $22.4 \%$ & $16.5 \%$ \\
\hline & 2006 & $38.6 \%$ & $9.5 \%$ & & $25.2 \%$ & $4.0 \%$ & $22.7 \%$ & $17.5 \%$ \\
\hline & 2009 & $35.4 \%$ & $8.2 \%$ & & $22.5 \%$ & $4.7 \%$ & $19.9 \%$ & $17.5 \%$ \\
\hline \multirow[t]{5}{*}{ Thailand } & 1985 & $39.0 \%$ & $13.4 \%$ & $3.8 \%$ & $15.4 \%$ & $6.3 \%$ & $20.9 \%$ & $19.8 \%$ \\
\hline & 1995 & $47.7 \%$ & $16.8 \%$ & $2.9 \%$ & $23.0 \%$ & $4.9 \%$ & $18.9 \%$ & $15.1 \%$ \\
\hline & 2003 & $48.9 \%$ & $14.2 \%$ & $7.1 \%$ & $17.9 \%$ & $9.7 \%$ & $18.2 \%$ & $14.7 \%$ \\
\hline & 2006 & $47.9 \%$ & $12.7 \%$ & $9.0 \%$ & $16.6 \%$ & $9.6 \%$ & $16.0 \%$ & $13.0 \%$ \\
\hline & 2009 & $45.6 \%$ & $10.3 \%$ & $10.6 \%$ & $14.6 \%$ & $10.1 \%$ & $11.8 \%$ & $10.6 \%$ \\
\hline \multirow[t]{5}{*}{ Malaysia } & 1985 & $60.2 \%$ & $23.8 \%$ & $1.1 \%$ & $29.1 \%$ & $6.3 \%$ & $13.7 \%$ & $14.9 \%$ \\
\hline & 1995 & $53.1 \%$ & $12.7 \%$ & $2.7 \%$ & $31.6 \%$ & $6.2 \%$ & $21.5 \%$ & $14.2 \%$ \\
\hline & 2003 & $53.7 \%$ & $10.7 \%$ & $6.5 \%$ & $28.7 \%$ & $7.8 \%$ & $20.2 \%$ & $12.1 \%$ \\
\hline & 2006 & $52.0 \%$ & $8.9 \%$ & $7.2 \%$ & $26.7 \%$ & $9.2 \%$ & $19.4 \%$ & $12.1 \%$ \\
\hline & 2009 & $57.4 \%$ & $9.8 \%$ & $12.2 \%$ & $25.6 \%$ & $9.8 \%$ & $11.5 \%$ & $10.3 \%$ \\
\hline
\end{tabular}




\begin{tabular}{|l|r|rrrrrrr|}
\hline Philippines & 1985 & $39.6 \%$ & $18.9 \%$ & $1.6 \%$ & $12.9 \%$ & $6.1 \%$ & $37.5 \%$ & $16.2 \%$ \\
& 1995 & $40.5 \%$ & $15.9 \%$ & $1.2 \%$ & $16.2 \%$ & $7.2 \%$ & $37.4 \%$ & $16.9 \%$ \\
& 2003 & $57.7 \%$ & $22.3 \%$ & $6.2 \%$ & $21.5 \%$ & $7.7 \%$ & $12.7 \%$ & $13.1 \%$ \\
& 2006 & $58.9 \%$ & $21.6 \%$ & $8.3 \%$ & $20.9 \%$ & $8.2 \%$ & $11.7 \%$ & $11.5 \%$ \\
& 2009 & $56.8 \%$ & $15.9 \%$ & $9.8 \%$ & $20.4 \%$ & $10.6 \%$ & $9.7 \%$ & $11.0 \%$ \\
\hline Indonesia & 1985 & $64.7 \%$ & $46.2 \%$ & $0.5 \%$ & $16.1 \%$ & $1.9 \%$ & $22.0 \%$ & $6.4 \%$ \\
& 1995 & $58.1 \%$ & $27.1 \%$ & $3.8 \%$ & $22.2 \%$ & $5.0 \%$ & $14.7 \%$ & $14.9 \%$ \\
& 2003 & $58.4 \%$ & $15.9 \%$ & $5.9 \%$ & $25.5 \%$ & $11.0 \%$ & $21.0 \%$ & $16.3 \%$ \\
& 2006 & $58.0 \%$ & $16.7 \%$ & $9.8 \%$ & $22.4 \%$ & $9.1 \%$ & $18.9 \%$ & $18.0 \%$ \\
& 2009 & $54.5 \%$ & $16.2 \%$ & $7.6 \%$ & $23.0 \%$ & $7.7 \%$ & $18.3 \%$ & $20.3 \%$ \\
\hline North & 1985 & $17.9 \%$ & $8.8 \%$ & $1.6 \%$ & $5.9 \%$ & $1.6 \%$ & $37.9 \%$ & $18.9 \%$ \\
America & 1995 & $24.8 \%$ & $9.5 \%$ & $1.9 \%$ & $10.2 \%$ & $3.3 \%$ & $35.9 \%$ & $17.5 \%$ \\
& 2003 & $19.4 \%$ & $5.8 \%$ & $3.2 \%$ & $7.6 \%$ & $2.9 \%$ & $40.5 \%$ & $16.6 \%$ \\
& 2006 & $18.8 \%$ & $4.8 \%$ & $4.3 \%$ & $7.3 \%$ & $2.3 \%$ & $38.4 \%$ & $16.3 \%$ \\
& 2009 & $19.5 \%$ & $4.3 \%$ & $5.8 \%$ & $7.2 \%$ & $2.2 \%$ & $32.1 \%$ & $17.4 \%$ \\
\hline EU 15 & 1985 & $4.2 \%$ & $1.2 \%$ & $0.8 \%$ & $1.5 \%$ & $0.7 \%$ & $10.8 \%$ & $57.8 \%$ \\
& 1995 & $7.8 \%$ & $2.1 \%$ & $1.0 \%$ & $3.2 \%$ & $1.6 \%$ & $7.3 \%$ & $61.8 \%$ \\
& 2003 & $6.2 \%$ & $1.6 \%$ & $1.6 \%$ & $2.2 \%$ & $0.9 \%$ & $9.7 \%$ & $60.9 \%$ \\
& 2006 & $6.2 \%$ & $1.3 \%$ & $1.9 \%$ & $2.1 \%$ & $0.8 \%$ & $9.0 \%$ & $59.1 \%$ \\
& 2009 & $7.2 \%$ & $1.2 \%$ & $2.7 \%$ & $2.4 \%$ & $0.9 \%$ & $7.7 \%$ & $57.0 \%$ \\
\hline
\end{tabular}

(Source) Compiled from UN Comtrade data base, Author's calculation

The NIEs also increased its importance in intra-East Asian imports between 1985 and 2006. The share increased from $10.7 \%$ in 1985 to $18.4 \%$ in 2006 . On the other hand, the table reports relatively small gain in the share of the ASEAN by 3.6\% between 1985 and 2006. In contrast, a sizeable decline is observed in the share of Japan by almost $11.3 \%$ during the same period and the share further declined by 1.5\% from 2006 and 2009. The shares of North America in the East Asian imports also declined, however, by lower amount relative to the Japanese experience. In contrast, the share of imports from EU15 rebounded from 2006 to 2009 on the back of a general declining trend.

Increased dependency on regional trade can be seen for all East Asian countries, although sizeable differences regarding the extent of the dependence exist among those countries. At the same time, the dependence on North America and EU 15 as an import source declined for all East Asian countries except for Japan and Singapore where the share of EU 15 increased slightly.

The increased importance of China as an import source country can be seen in all East Asian countries, particularly for more advanced nations such as Japan, Korea, Taiwan and Hong Kong. China has also become an increasingly important factor for non-regional markets. The increase in the share of China in the imports of North America between 1985 and 2009 was $17.0 \%$. In spite of the fact that intra-regional imports dominate in EU15 accounting for $53.1 \%$ in 2009 , China managed to gain its share by $6.7 \%$ since 1985 . For both regions, China accounts for approximately 55\% of their imports from the East Asia in 2009.

The table shows that there have been significant changes in the pattern of China's imports. In 1985, more than one third of its imports originated from Japan. Two decades later, its 
reliance on Japan has declined to $13.0 \%$. On the other hand, a large increase in the share of NIEs is witnessed.

A similar pattern of deepening trade ties among East Asian economies can be observed on the export side. The share of intra-regional exports increased from $42.4 \%$ in 1985 to $51.6 \%$ in 2003 followed by slight decline. In all countries examined, significantly higher increase in the share of intra-regional exports is reported for Taiwan by almost $38 \%$ and Japan by $27.4 \%$ followed by Hong Kong and Korea by $22.3 \%$ and $21.1 \%$, respectively. The increase in the share of intra-regional exports in all countries is largely attributed to China and to a lesser extent to NIEs. If we exclude Japan from East Asia, increased dependency on regional trade is evidenced for all other Asian countries except China.

The share of NIEs bound and ASEAN4 bound exports from China shrank from $36.4 \%$ to 27.2\% between 1985 and 2009. In contrast, much higher portion of Chinese goods is absorbed by both North America and to a lesser extent by EU15 in 2009 As we have shown in the import side, the reliance on North America declined for all other East Asian countries except China. The decline in that reliance appears to be even larger on the export side. Taiwan in particular, the share of North America declined from 51.4\% in 1985 to $12.3 \%$ in 2009.

\section{B. Trade by production stage in East Asia}

The above section leads to the conclusion that East Asian countries have generally become increasingly interdependent in trade. This section considers composition of trade by stage of production in East Asia.

Table 2. Average growth rate of imports and exports by production stage

(1998 2009)

\begin{tabular}{|c|c|c|c|c|c|c|}
\hline \multirow[b]{2}{*}{ Countries } & \multicolumn{3}{|c|}{ Imports } & \multicolumn{3}{|c|}{ Exports } \\
\hline & Total & $\begin{array}{l}\text { ntermedi } \\
\text { Goods }\end{array}$ & $\begin{array}{l}\text { Final } \\
\text { Goods }\end{array}$ & Total & $\begin{array}{l}\text { Intermediate } \\
\text { Goods }\end{array}$ & $\begin{array}{r}\text { Final } \\
\text { Goods }\end{array}$ \\
\hline Eight Asian Nations & $9.9 \%$ & $10.8 \%$ & $8.4 \%$ & $9.9 \%$ & $10.4 \%$ & $9.5 \%$ \\
\hline Japan & $6.0 \%$ & $7.3 \%$ & $4.7 \%$ & $4.4 \%$ & $5.5 \%$ & $2.6 \%$ \\
\hline China & $18.3 \%$ & $17.8 \%$ & $19.5 \%$ & $19.9 \%$ & $21.7 \%$ & $18.9 \%$ \\
\hline Hong Kong & $6.2 \%$ & $8.1 \%$ & $4.0 \%$ & $6.3 \%$ & $9.4 \%$ & $3.3 \%$ \\
\hline Indonesia & $15.1 \%$ & $15.3 \%$ & $15.3 \%$ & $7.6 \%$ & $10.5 \%$ & $8.4 \%$ \\
\hline Malaysia & $7.2 \%$ & $7.1 \%$ & $7.8 \%$ & $7.3 \%$ & $7.9 \%$ & $6.0 \%$ \\
\hline Philippines & $2.7 \%$ & $2.4 \%$ & $4.7 \%$ & $2.8 \%$ & $2.0 \%$ & $5.0 \%$ \\
\hline Rep. of Korea & $12.6 \%$ & $11.5 \%$ & $16.1 \%$ & $10.0 \%$ & $9.5 \%$ & $10.9 \%$ \\
\hline Singapore & $7.4 \%$ & $8.0 \%$ & $5.4 \%$ & $8.6 \%$ & $10.6 \%$ & $2.8 \%$ \\
\hline Thailand & $10.7 \%$ & $11.2 \%$ & $10.7 \%$ & $9.9 \%$ & $11.0 \%$ & $9.5 \%$ \\
\hline EU15 & $7.0 \%$ & $6.4 \%$ & $6.9 \%$ & $6.9 \%$ & $6.6 \%$ & $6.6 \%$ \\
\hline North America & $4.3 \%$ & $3.5 \%$ & $5.0 \%$ & $3.6 \%$ & $3.2 \%$ & $3.1 \%$ \\
\hline World & $7.4 \%$ & $7.4 \%$ & $7.0 \%$ & $7.5 \%$ & $7.4 \%$ & $7.2 \%$ \\
\hline
\end{tabular}

(Source) Compiled from UN Comtrade data base, Author's calculation 
Table 2 examines the annual growth rate of trade in total manufactured goods and compares them with the rate of trade in finished and intermediate goods. The table provides strong evidence that trade in intermediate goods resulting from the international fragmentation of production has been the driving force of Asian trade during recent years. Between 1998 and 2009 , exports of intermediate goods grew at a rate of $10.4 \%$ among Asian nations on average, which is faster than the growth rate of $9.5 \%$ for exports of final goods. On the import side, trade in intermediate goods grew over $2.4 \%$ point faster than trade in final goods. Compared with other parts of the world, the growth rate in intermediate goods is much faster among Asian nations, both for exports and imports. The growth rate of exports of intermediate goods for the world, the EU 15 and North America was 7.4\%, 6.6\% and 3.2\%, respectively while that of imports was $7.4 \%, 6.4 \%$ and $3.5 \%$, respectively. This reflects the fact that international fragmentation of production has prevailed more among the countries of East Asia relative to other regions of the world.

Table 3. Trade partner by production stage

\begin{tabular}{|c|c|c|c|c|c|c|c|c|c|c|c|c|c|c|}
\hline Imports & stage & China & $\begin{array}{c}\text { China, } \\
\text { Hong Kong } \\
\text { SAR }\end{array}$ & Indonesia & Japan & Malaysia & Philippines & $\begin{array}{l}\text { Rep. of } \\
\text { Korea }\end{array}$ & Singapore & Thailand & Asia & $\begin{array}{c}\text { North } \\
\text { America }\end{array}$ & $\begin{array}{l}\text { European } \\
\text { Union } 15\end{array}$ & World \\
\hline \multirow[t]{5}{*}{1998} & $\mathrm{FC}$ & $4.4 \%$ & $32.9 \%$ & $6.1 \%$ & $28.3 \%$ & $6.2 \%$ & $8.6 \%$ & $5.0 \%$ & $12.7 \%$ & $8.3 \%$ & $18.3 \%$ & $29.5 \%$ & $27.4 \%$ & $24.8 \%$ \\
\hline & FCA & $19.4 \%$ & $15.6 \%$ & $21.5 \%$ & $12.7 \%$ & $18.2 \%$ & $10.4 \%$ & $12.0 \%$ & $21.0 \%$ & $17.3 \%$ & $15.8 \%$ & $18.1 \%$ & $16.1 \%$ & $17.0 \%$ \\
\hline & IMPC & $21.8 \%$ & $19.2 \%$ & $16.3 \%$ & $13.2 \%$ & $46.1 \%$ & $46.7 \%$ & $24.3 \%$ & $39.7 \%$ & $26.7 \%$ & $23.3 \%$ & $21.1 \%$ & $17.6 \%$ & $18.9 \%$ \\
\hline & IMSF & $44.5 \%$ & $28.6 \%$ & $37.5 \%$ & $23.6 \%$ & $21.7 \%$ & $24.7 \%$ & $33.0 \%$ & $16.4 \%$ & $34.6 \%$ & $28.6 \%$ & $20.1 \%$ & $27.7 \%$ & $27.1 \%$ \\
\hline & $\mathrm{P}$ & $8.2 \%$ & $2.1 \%$ & $12.6 \%$ & $19.1 \%$ & $3.7 \%$ & $9.5 \%$ & $22.7 \%$ & $6.0 \%$ & $11.2 \%$ & $11.4 \%$ & $6.4 \%$ & $7.7 \%$ & $8.3 \%$ \\
\hline \multirow[t]{5}{*}{2002} & $\mathrm{FC}$ & $4.5 \%$ & $29.6 \%$ & $6.6 \%$ & $27.7 \%$ & $7.6 \%$ & $6.9 \%$ & $9.8 \%$ & $11.9 \%$ & $7.6 \%$ & $16.1 \%$ & $32.1 \%$ & $28.8 \%$ & $25.3 \%$ \\
\hline & FCA & $21.0 \%$ & $16.0 \%$ & $14.0 \%$ & $12.3 \%$ & $15.0 \%$ & $7.0 \%$ & $14.5 \%$ & $17.2 \%$ & $17.5 \%$ & $15.8 \%$ & $17.4 \%$ & $14.9 \%$ & $16.1 \%$ \\
\hline & IMPC & $27.4 \%$ & $26.9 \%$ & $13.8 \%$ & $14.4 \%$ & $47.0 \%$ & $55.5 \%$ & $22.7 \%$ & $41.4 \%$ & $27.1 \%$ & $26.4 \%$ & $17.4 \%$ & $16.5 \%$ & $18.5 \%$ \\
\hline & IMSF & $34.7 \%$ & $24.2 \%$ & $35.6 \%$ & $22.5 \%$ & $20.8 \%$ & $19.4 \%$ & $29.5 \%$ & $14.7 \%$ & $31.6 \%$ & $26.2 \%$ & $19.0 \%$ & $25.7 \%$ & $25.3 \%$ \\
\hline & P & $10.6 \%$ & $2.0 \%$ & $19.5 \%$ & $19.3 \%$ & $4.7 \%$ & $9.5 \%$ & $20.2 \%$ & $7.0 \%$ & $14.3 \%$ & $12.3 \%$ & $8.7 \%$ & $9.1 \%$ & $10.0 \%$ \\
\hline \multirow[t]{5}{*}{2006} & $\mathrm{FC}$ & $4.2 \%$ & $21.6 \%$ & $6.5 \%$ & $20.8 \%$ & $7.5 \%$ & $7.7 \%$ & $8.3 \%$ & $9.0 \%$ & $7.7 \%$ & $11.4 \%$ & $27.9 \%$ & $25.8 \%$ & $21.5 \%$ \\
\hline & FCA & $19.2 \%$ & $16.1 \%$ & $14.6 \%$ & $11.0 \%$ & $14.4 \%$ & $6.6 \%$ & $14.6 \%$ & $14.6 \%$ & $14.3 \%$ & $15.2 \%$ & $16.4 \%$ & $14.2 \%$ & $15.5 \%$ \\
\hline & IMPC & $30.5 \%$ & $36.2 \%$ & $10.5 \%$ & $13.7 \%$ & $41.4 \%$ & $48.4 \%$ & $17.6 \%$ & $40.7 \%$ & $22.9 \%$ & $27.0 \%$ & $15.1 \%$ & $14.5 \%$ & $17.3 \%$ \\
\hline & IMSF & $26.0 \%$ & $21.5 \%$ & $31.3 \%$ & $23.5 \%$ & $22.9 \%$ & $19.6 \%$ & $30.3 \%$ & $14.3 \%$ & $32.0 \%$ & $24.4 \%$ & $20.3 \%$ & $26.1 \%$ & $25.2 \%$ \\
\hline & $\mathrm{P}$ & $17.9 \%$ & $2.1 \%$ & $19.2 \%$ & $26.8 \%$ & $7.6 \%$ & $13.2 \%$ & $26.1 \%$ & $9.3 \%$ & $20.3 \%$ & $17.6 \%$ & $14.0 \%$ & $12.1 \%$ & $13.5 \%$ \\
\hline \multirow[t]{5}{*}{2009} & $\mathrm{FC}$ & $5.3 \%$ & $22.6 \%$ & $7.8 \%$ & $24.2 \%$ & $9.7 \%$ & $14.0 \%$ & $8.7 \%$ & $11.1 \%$ & $9.2 \%$ & $12.5 \%$ & $30.0 \%$ & $29.7 \%$ & $23.5 \%$ \\
\hline & FCA & $17.1 \%$ & $17.0 \%$ & $23.1 \%$ & $10.4 \%$ & $15.9 \%$ & $7.7 \%$ & $13.8 \%$ & $16.2 \%$ & $14.4 \%$ & $15.2 \%$ & $18.0 \%$ & $13.1 \%$ & $15.4 \%$ \\
\hline & IMPC & $27.7 \%$ & $39.0 \%$ & $17.5 \%$ & $12.4 \%$ & $37.7 \%$ & $40.4 \%$ & $18.7 \%$ & $41.1 \%$ & $23.5 \%$ & $26.2 \%$ & $14.7 \%$ & $14.0 \%$ & $17.1 \%$ \\
\hline & IMSF & $26.2 \%$ & $19.0 \%$ & $36.1 \%$ & $24.4 \%$ & $26.6 \%$ & $23.0 \%$ & $32.3 \%$ & $17.0 \%$ & $32.9 \%$ & $25.5 \%$ & $19.3 \%$ & $25.9 \%$ & $25.6 \%$ \\
\hline & $\mathrm{P}$ & $23.5 \%$ & $2.3 \%$ & $15.2 \%$ & $26.7 \%$ & $9.4 \%$ & $14.9 \%$ & $26.4 \%$ & $11.0 \%$ & $19.8 \%$ & $19.7 \%$ & $14.5 \%$ & $12.2 \%$ & $14.3 \%$ \\
\hline
\end{tabular}

(Note) FC: Consumption goods FCA: Capital goods IMPC: parts and components IM SF: semi-finished goods, P: primary goods

(Source) Compiled from UN Comtrade data base, Author's calculation 


\begin{tabular}{|c|c|c|c|c|c|c|c|c|c|c|c|c|c|c|}
\hline Exports & stage & China & $\begin{array}{c}\text { China, } \\
\text { Hong Kong } \\
\text { SAR }\end{array}$ & Indonesia & Japan & Malaysia & Philippines & $\begin{array}{c}\text { Rep. of } \\
\text { Korea }\end{array}$ & Singapore & Thailand & Asia & $\begin{array}{c}\text { North } \\
\text { America }\end{array}$ & $\begin{array}{l}\text { European } \\
\text { Union } 15\end{array}$ & World \\
\hline \multirow[t]{5}{*}{1998} & FC & $47.9 \%$ & $42.6 \%$ & $20.5 \%$ & $20.0 \%$ & $14.0 \%$ & $17.7 \%$ & $19.2 \%$ & $10.9 \%$ & $37.4 \%$ & $27.0 \%$ & $16.6 \%$ & $27.2 \%$ & $24.9 \%$ \\
\hline & FCA & $15.0 \%$ & $12.3 \%$ & $4.1 \%$ & $27.4 \%$ & $18.5 \%$ & $12.2 \%$ & $20.2 \%$ & $28.4 \%$ & $13.0 \%$ & $20.1 \%$ & $21.3 \%$ & $19.2 \%$ & $17.9 \%$ \\
\hline & IMPC & $9.8 \%$ & $17.6 \%$ & $4.7 \%$ & $29.6 \%$ & $36.5 \%$ & $59.6 \%$ & $22.0 \%$ & $37.4 \%$ & $24.8 \%$ & $24.6 \%$ & $26.3 \%$ & $17.9 \%$ & $19.4 \%$ \\
\hline & IMSF & $22.9 \%$ & $24.9 \%$ & $36.3 \%$ & $19.4 \%$ & $23.9 \%$ & $9.0 \%$ & $34.5 \%$ & $13.9 \%$ & $18.8 \%$ & $22.6 \%$ & $24.1 \%$ & $28.3 \%$ & $26.5 \%$ \\
\hline & $\mathrm{P}$ & $3.8 \%$ & $1.5 \%$ & $17.5 \%$ & $0.4 \%$ & $5.3 \%$ & $1.5 \%$ & $0.8 \%$ & $0.8 \%$ & $4.0 \%$ & $2.3 \%$ & $6.8 \%$ & $3.1 \%$ & $7.0 \%$ \\
\hline \multirow[t]{5}{*}{2002} & FC & $40.2 \%$ & $35.9 \%$ & $20.8 \%$ & $22.4 \%$ & $12.7 \%$ & $14.8 \%$ & $19.4 \%$ & $8.5 \%$ & $33.1 \%$ & $26.3 \%$ & $17.6 \%$ & $29.2 \%$ & $25.1 \%$ \\
\hline & FCA & $20.0 \%$ & $14.7 \%$ & $8.2 \%$ & $23.0 \%$ & $18.8 \%$ & $17.0 \%$ & $26.2 \%$ & $22.0 \%$ & $14.9 \%$ & $20.1 \%$ & $18.9 \%$ & $18.3 \%$ & $16.7 \%$ \\
\hline & IMPC & $15.6 \%$ & $25.5 \%$ & $8.7 \%$ & $29.6 \%$ & $38.2 \%$ & $59.3 \%$ & $24.3 \%$ & $42.8 \%$ & $23.3 \%$ & $26.7 \%$ & $25.7 \%$ & $17.1 \%$ & $19.0 \%$ \\
\hline & IMSF & $20.3 \%$ & $22.2 \%$ & $40.4 \%$ & $20.2 \%$ & $22.2 \%$ & $6.5 \%$ & $25.9 \%$ & $15.1 \%$ & $19.9 \%$ & $21.3 \%$ & $24.4 \%$ & $27.0 \%$ & $24.8 \%$ \\
\hline & P & $2.9 \%$ & $1.4 \%$ & $19.5 \%$ & $0.4 \%$ & $5.1 \%$ & $1.4 \%$ & $0.3 \%$ & $0.7 \%$ & $4.5 \%$ & $2.4 \%$ & $7.5 \%$ & $3.4 \%$ & $8.9 \%$ \\
\hline \multirow[t]{5}{*}{2006} & FC & $31.1 \%$ & $26.5 \%$ & $17.1 \%$ & $20.6 \%$ & $10.6 \%$ & $13.2 \%$ & $14.8 \%$ & $7.7 \%$ & $27.2 \%$ & $22.4 \%$ & $16.6 \%$ & $26.8 \%$ & $22.1 \%$ \\
\hline & FCA & $26.8 \%$ & $14.9 \%$ & $5.8 \%$ & $22.1 \%$ & $20.4 \%$ & $15.6 \%$ & $27.6 \%$ & $14.4 \%$ & $17.9 \%$ & $21.8 \%$ & $18.9 \%$ & $18.2 \%$ & $16.6 \%$ \\
\hline & IMPC & $17.4 \%$ & $36.4 \%$ & $7.1 \%$ & $28.5 \%$ & $30.9 \%$ & $53.7 \%$ & $25.9 \%$ & $44.4 \%$ & $21.3 \%$ & $26.4 \%$ & $22.1 \%$ & $16.3 \%$ & $17.6 \%$ \\
\hline & IMSF & $22.2 \%$ & $20.3 \%$ & $41.8 \%$ & $22.5 \%$ & $25.3 \%$ & $12.6 \%$ & $25.1 \%$ & $16.1 \%$ & $22.6 \%$ & $22.5 \%$ & $26.1 \%$ & $28.1 \%$ & $25.7 \%$ \\
\hline & P & $1.4 \%$ & $1.6 \%$ & $25.5 \%$ & $0.9 \%$ & $8.4 \%$ & $2.5 \%$ & $0.5 \%$ & $0.7 \%$ & $6.6 \%$ & $2.6 \%$ & $10.2 \%$ & $4.2 \%$ & $11.3 \%$ \\
\hline \multirow[t]{5}{*}{2009} & FC & $30.4 \%$ & $23.4 \%$ & $17.3 \%$ & $16.7 \%$ & $12.8 \%$ & $13.4 \%$ & $11.5 \%$ & $10.3 \%$ & $30.2 \%$ & $22.0 \%$ & $17.9 \%$ & $29.7 \%$ & $23.7 \%$ \\
\hline & FCA & $30.2 \%$ & $17.1 \%$ & $6.3 \%$ & $20.9 \%$ & $15.4 \%$ & $23.6 \%$ & $34.5 \%$ & $13.8 \%$ & $17.6 \%$ & $24.1 \%$ & $15.7 \%$ & $16.4 \%$ & $16.4 \%$ \\
\hline & IMPC & $17.8 \%$ & $38.8 \%$ & $6.3 \%$ & $29.2 \%$ & $31.5 \%$ & $46.6 \%$ & $26.0 \%$ & $48.8 \%$ & $19.6 \%$ & $26.0 \%$ & $17.4 \%$ & $15.8 \%$ & $16.8 \%$ \\
\hline & IMSF & $20.3 \%$ & $19.1 \%$ & $40.0 \%$ & $26.0 \%$ & $32.6 \%$ & $12.8 \%$ & $27.4 \%$ & $18.6 \%$ & $27.7 \%$ & $23.5 \%$ & $27.0 \%$ & $28.1 \%$ & $26.0 \%$ \\
\hline & $\mathrm{P}$ & $1.0 \%$ & $1.5 \%$ & $30.1 \%$ & $1.2 \%$ & $7.3 \%$ & $3.5 \%$ & $0.5 \%$ & $0.6 \%$ & $4.9 \%$ & $2.6 \%$ & $12.5 \%$ & $3.7 \%$ & $12.1 \%$ \\
\hline
\end{tabular}

(Note) FC: Consumption goods FCA: Capital goods IMPC: parts and components

IM SF: semi-finished goods, P: primary goods

(Source) Compiled from UN Comtrade data base, Author's calculation

Table 3 further distinguishes different types of intermediate goods, i.e., parts and components (IMPC) and semi-finished goods (IMSF). Finished goods are also further classified into consumption goods (FC) and capital goods (FCA). Primary goods (P) form the last category. This classification by different stages of production is useful in showing how each nation of East Asia is involved in production fragmentation and to what extent they differ from other regions of the world. The classification is explained in Appendix 1.

The most notable difference between the rest of the world and the East Asian nations can be found in the trade pattern of parts and components. At the global level, approximately one fifth of both imports and exports comprise the exchange of parts and components. That share remained relatively stable between 1998 and 2009 although both import and export are on a slight declining trend in recent years. Table 3 shows very different trends for different regions. For example, North America experienced declines of $6.5 \%$ and $8.9 \%$, respectively, in its import and export share of parts and components from 1998 to 2009. The EU 15 also experienced a declining trend in its parts and components trade, although more moderately relative to North America. The trend in East Asia contrasts markedly with the other regions, with the share of the parts and components trade consistently accounts for approximately a quarter or more of total imports and exports during the same period.

For finished products, the most distinguishing difference between the rest of the world and the Asian nations can be found in the trade pattern of consumption goods, particularly on the import side. Approximately $24 \%$ of world imports take the form of consumption goods. In the case of North America and the EU15, the share is almost 30\%. Among the East Asian nations, the corresponding share only amounts to $12.5 \%$ in 2009 , which was a decline of almost $6 \%$ 
from 1998.

Another interesting point to note is the gradual decline in import share of capital goods which can be seen in all Asian countries examined except Hong Kong and Korea. However, one must use caution about BEC(Broad Economic Categories issued by the United Nations) classification for capital goods. Capital goods (41) include producers' goods that are defined in the System of National Accounts (SNA) as part of fixed capital formation. However, there are goods in capital goods (41 and 51) that can be used as intermediate products in the related industry. Examples include motors, diesel and semi-diesel engines, generators, transformers, radiators, rectifiers, and so on.

Furthermore, there is considerable variation in the trade patterns across East Asian countries. A general picture of the division of production processes in East Asia can be drawn from Table 4 as follows: China's trade structure can be characterized by a larger import share of parts and components and semi-finished products, and by a large export share of consumption goods as well as capital goods. This reflects China's role in production fragmentation as a processing and assembly base for finished products destined for the world market.

The general feature of three ASEAN countries, Malaysia, the Philippines, and Indonesia is a large share of intermediate goods among both imports and exports. The decomposition of intermediate goods shows that while parts and components account for a large share of imports and exports in Malaysia and the Philippines, semi-finished goods account for a large share in Indonesia. The import structure of Thailand is similar to the above-mentioned three ASEAN countries; however, the distinctive difference can be found in its export structure, i.e., a much larger share of exports of consumption goods. In this comparison, Singapore is treated separately from the four other ASEAN countries due to its relatively high wages, and it will be discussed subsequently.

Japan's trade structure is quite different from those of the developing Asian countries. Japan is a large supplier of parts and components, reflecting Japanese industries turning to other countries of the region for the assembly of Japanese products (Jones et al., 2004). The trend is also marked by a small export share of consumption goods. Table 3 also indicates that capital goods hold a large share of Japan's exports, which reflects in part large Foreign Direct Investment (FDI) outflows from Japan. Production fragmentation has been facilitated greatly by multinational corporations and consequent FDI, which has had a significant impact on exports from investing countries to host countries. This may be due to the fact that new production facilities need to be equipped using capital goods from the investing country or because new capital goods are required for expanding existing production capacities.

A large share of parts and components trade can also be found in countries such as Singapore and Hong Kong where wage costs are much higher relative to other developing countries of East Asia. In Singapore, parts and components make up a substantial share of its imports and exports. Over $41 \%$ of imports and $48 \%$ of exports are induced by the need for parts and components. This represents Singapore's pivotal role as an outsourcing centre in East 
Asia, particularly high-tech manufacturing, and as a hub for many leading international firms. Singapore's superior logistics sector as well as finance industry helps to form the world-class supply chains in the region.

Hong Kong as a trading hub for electronic parts and components in Asia hosts a number of multinational manufacturers which source parts of key components and take advantage of its free port status. At the same time, the electronics industry is characterized by the heavy dependence on imported parts of key components. Local firms source both worldwide and the mainland China. Hong Kong's import share of parts and components increased dramatically from $19.2 \%$ in 1998 to $39.0 \%$ in 2009 . On the export side, electronics industry is the largest export industry, accounting for nearly $50 \%$ of its total exports in 2006. Furthermore, two-thirds of electronics exports comprise parts and components. What contributes to the large amount of parts and components exports is its involvement in outward processing production in China. This led to an increase in the export share from $17.6 \%$ in 1998 to $38.8 \%$ in 2009 .

\section{General Trend in FDI in East Asia}

Table 4 shows that although global FDI inflow continued to be dominated by the EU15 since 1980, East Asia (without Japan) has gained in importance as recipients of FDI over time until mid-1990s in terms of both the volume of inward flows and their world share. Total value of inflows of FDI into eight East Asian economies that amounted to US\$ 4.5 billion in 1985 increased to US\$ 71.8 billion in 1995. Their share in total world inflows rose from $7.7 \%$ in 1985 to $21.1 \%$ in 1995 . The surge of FDI came to a halt however in 1997 with the Asian financial crisis. The swift recovery from the crisis in terms of FDI volume in 1998 was only followed by another sharp downturn in 2001. Since 2003, FDI inflow to the region has been on a rise again. It reached US\$ 132.51 billion in 2004, a 56\% increase over 2003 with a backdrop of improved economic performance, a more favorable FDI policy environment and a rise in merger and acquisition activities in the region. Considering 30\% increase in global FDI inflow in 2004, a gain in the region's FDI inflow is spectacular. It continued to grow until 2008 reaching US\$ 219 billion which was up to forty nine-fold from 1985. The global financial crisis had a major dampening effect on global FDI inflow in 2008 among developed countries and spread to developing countries in late 2008 and early 2009. In the midst of the turmoil, however, total inflow of FDI in East Asia managed to increase slightly in 2008 because of the increased FDI inflow to Korea, Hong Kong, Indonesia, and China during the year countervailed the decreased FDI inflow to the rest of East Asian economies. The region finally faced a downturn in FDI inflows in 2009, although the share of East Asia in global FDI flows surged from $10.2 \%$ to $16.4 \%$ in 2009 as FDI flows to developed countries further contracted during the year. 
Table 4. Inward FDI and its share in the World Inward FDI

(Unit: US\$ million)

\begin{tabular}{|l|rrrrrrrrrrrrr|}
\hline & \multicolumn{1}{|c}{1985} & \multicolumn{1}{c}{1990} & \multicolumn{1}{c}{1995} & \multicolumn{1}{c}{2000} & \multicolumn{1}{c}{2001} & \multicolumn{1}{c}{2002} & 2003 & 2004 & 2005 & 2006 & 2007 & 2008 & 2009 \\
\hline Japan & 642.0 & $1,753.0$ & 41.5 & $8,322.7$ & $6,241.3$ & $9,239.3$ & $6,324.3$ & $7,815.7$ & $2,775.0$ & $-6,506$ & 22,550 & 24,426 & 11,939 \\
Republic of Korea & 218.0 & 759.0 & $1,250.0$ & $8,591.0$ & $3,692.0$ & $2,975.0$ & $3,785.0$ & $7,687.0$ & $7,198.0$ & 4,950 & 2,628 & 8,409 & 5,844 \\
Taiwan Province of China & 342.0 & $1,330.0$ & $1,559.0$ & $4,928.0$ & $4,109.0$ & $1,445.0$ & 453.0 & $1,898.0$ & $1,625.0$ & 7,424 & 7,769 & 5,432 & 2,803 \\
Hong Kong, China & -267.2 & $3,275.1$ & $6,213.4$ & $61,924.1$ & $23,776.5$ & $9,681.9$ & $13,623.6$ & $34,034.7$ & $35,897.0$ & 42,892 & 54,341 & 59,621 & 48,449 \\
China & $1,956.0$ & $3,487.1$ & $37,520.5$ & $40,714.8$ & $46,877.6$ & $52,742.9$ & $53,505.0$ & $60,630.0$ & $72,406.0$ & 69,468 & 83,521 & 108,312 & 95,000 \\
Singapore & $1,046.8$ & $5,574.7$ & $11,591.3$ & $16,484.5$ & $14,121.6$ & $5,821.5$ & $9,330.8$ & $16,059.8$ & $20,083.0$ & 24,207 & 35,778 & 10,912 & 16,809 \\
Thailand & 160.0 & $2,575.0$ & $2,070.0$ & $3,350.0$ & $3,886.0$ & 947.0 & $1,952.0$ & $5,862.0$ & $8,957.0$ & 9,751 & 11,355 & 8,544 & 5,949 \\
Malysia & 694.7 & $2,611.0$ & $5,815.0$ & $3,787.6$ & 553.9 & $3,203.4$ & $2,473.2$ & $4,624.0$ & $3,965.0$ & 6,060 & 8,538 & 7,318 & 1,381 \\
Phillipines & 12.0 & 550.0 & $1,459.0$ & $1,345.0$ & 899.0 & $1,792.0$ & 347.0 & 688.0 & $1,854.0$ & 2,345 & 2,916 & 1,544 & 1,948 \\
Indonesia & 310.0 & $1,092.0$ & $4,346.0$ & $-4,550.0$ & $-2,978.4$ & 145.0 & -596.9 & $1,023.0$ & $5,260.0$ & 5,556 & 6,928 & 9,318 & 4,877 \\
\hline E. Asia & $4,472.2$ & $21,253.9$ & $71,824.2$ & $136,575.0$ & $94,937.2$ & $78,753.7$ & $84,872.6$ & $132,506.5$ & $157,245.0$ & $172,653.0$ & $213,774.0$ & $219,410.0$ & $183,060.0$ \\
ASEAN5 & $2,223.5$ & $12,402.7$ & $25,281.3$ & $20,417.1$ & $16,482.1$ & $11,908.9$ & $13,506.0$ & $28,256.8$ & $40,119.0$ & $47,919.0$ & $65,515.0$ & $37,636.0$ & $30,964.0$ \\
N.America & $21,862.0$ & $21,862.0$ & $21,862.0$ & $21,862.0$ & $21,862.0$ & $21,862.0$ & $21,862.0$ & $21,862.0$ & $21,862.0$ & 135,462 & 374,371 & 379,830 & 148,540 \\
EU15 & $15,965.0$ & $89,459.0$ & $116,324.0$ & $674,278.0$ & $362,418.0$ & $283,863.0$ & $240,572.0$ & $185,227.0$ & $387,858.0$ & 492,090 & 778,602 & 414,979 & 333,932 \\
\hline World & $57,959.0$ & $201,614.0$ & $340,336.0$ & $1,409,568.0$ & $832,248.0$ & $617,732.0$ & $557,869.0$ & $710,755.0$ & $916,277.0$ & $1,305,852$ & $2,099,973$ & $1,770,873$ & $1,113,189$ \\
\hline
\end{tabular}

(Unit: \%)

\begin{tabular}{|l|rrrrrrrrrrrrr}
\hline & \multicolumn{1}{|c}{1985} & 1990 & 1995 & 2000 & 2001 & 2002 & 2003 & 2004 & 2005 & 2006 & 2007 & 2008 & 2009 \\
\hline Japan & $1.1 \%$ & $0.9 \%$ & $0.0 \%$ & $0.6 \%$ & $0.7 \%$ & $1.5 \%$ & $1.1 \%$ & $1.1 \%$ & $0.3 \%$ & $-0.5 \%$ & $1.1 \%$ & $1.4 \%$ & $1.1 \%$ \\
Republic of Korea & $0.4 \%$ & $0.4 \%$ & $0.4 \%$ & $0.6 \%$ & $0.4 \%$ & $0.5 \%$ & $0.7 \%$ & $1.1 \%$ & $0.8 \%$ & $0.4 \%$ & $0.1 \%$ & $0.5 \%$ & $0.5 \%$ \\
Taiwan Province of China & $0.6 \%$ & $0.7 \%$ & $0.5 \%$ & $0.3 \%$ & $0.5 \%$ & $0.2 \%$ & $0.1 \%$ & $0.3 \%$ & $0.2 \%$ & $0.6 \%$ & $0.4 \%$ & $0.3 \%$ & $0.3 \%$ \\
Hong Kong, China & $-0.5 \%$ & $1.6 \%$ & $1.8 \%$ & $4.4 \%$ & $2.9 \%$ & $1.6 \%$ & $2.4 \%$ & $4.8 \%$ & $3.9 \%$ & $3.3 \%$ & $2.6 \%$ & $3.4 \%$ & $4.4 \%$ \\
China & $3.4 \%$ & $1.7 \%$ & $11.0 \%$ & $2.9 \%$ & $5.6 \%$ & $8.5 \%$ & $9.6 \%$ & $8.5 \%$ & $7.9 \%$ & $5.3 \%$ & $4.0 \%$ & $6.1 \%$ & $8.5 \%$ \\
Singapore & $1.8 \%$ & $2.8 \%$ & $3.4 \%$ & $1.2 \%$ & $1.7 \%$ & $0.9 \%$ & $1.7 \%$ & $2.3 \%$ & $2.2 \%$ & $1.9 \%$ & $1.7 \%$ & $0.6 \%$ & $1.5 \%$ \\
Thailand & $0.3 \%$ & $1.3 \%$ & $0.6 \%$ & $0.2 \%$ & $0.5 \%$ & $0.2 \%$ & $0.3 \%$ & $0.8 \%$ & $1.0 \%$ & $0.7 \%$ & $0.5 \%$ & $0.5 \%$ & $0.5 \%$ \\
Malysia & $1.2 \%$ & $1.3 \%$ & $1.7 \%$ & $0.3 \%$ & $0.1 \%$ & $0.5 \%$ & $0.4 \%$ & $0.7 \%$ & $0.4 \%$ & $0.5 \%$ & $0.4 \%$ & $0.4 \%$ & $0.1 \%$ \\
Phillipines & $0.0 \%$ & $0.3 \%$ & $0.4 \%$ & $0.1 \%$ & $0.1 \%$ & $0.3 \%$ & $0.1 \%$ & $0.1 \%$ & $0.2 \%$ & $0.2 \%$ & $0.1 \%$ & $0.1 \%$ & $0.2 \%$ \\
Indonesia & $0.5 \%$ & $0.5 \%$ & $1.3 \%$ & $-0.3 \%$ & $-0.4 \%$ & $0.0 \%$ & $-0.1 \%$ & $0.1 \%$ & $0.6 \%$ & $0.4 \%$ & $0.3 \%$ & $0.5 \%$ & $0.4 \%$ \\
\hline E. Asia & $7.7 \%$ & $10.5 \%$ & $21.1 \%$ & $9.7 \%$ & $11.4 \%$ & $12.7 \%$ & $15.2 \%$ & $18.6 \%$ & $17.2 \%$ & $13.2 \%$ & $10.2 \%$ & $12.4 \%$ & $16.4 \%$ \\
ASEAN5 & $3.8 \%$ & $6.2 \%$ & $7.4 \%$ & $1.4 \%$ & $2.0 \%$ & $1.9 \%$ & $2.4 \%$ & $4.0 \%$ & $4.4 \%$ & $3.7 \%$ & $3.1 \%$ & $2.1 \%$ & $2.8 \%$ \\
N.America & $37.7 \%$ & $10.8 \%$ & $6.4 \%$ & $1.6 \%$ & $2.6 \%$ & $3.5 \%$ & $3.9 \%$ & $3.1 \%$ & $2.4 \%$ & $10.4 \%$ & $17.8 \%$ & $21.4 \%$ & $13.3 \%$ \\
EU15 & $27.5 \%$ & $44.4 \%$ & $34.2 \%$ & $47.8 \%$ & $43.5 \%$ & $46.0 \%$ & $43.1 \%$ & $26.1 \%$ & $42.3 \%$ & $37.7 \%$ & $37.1 \%$ & $23.4 \%$ & $30.0 \%$ \\
\hline
\end{tabular}

(Note) East Asia excludes Japan

(Source) World Investment Report, various years

The largest contributor to the region's rising share in global FDI inflow has been China. FDI inflow to China has grown dramatically over the past two decades since China initiated its "open-door" policy in 1978. It was in the mid-1980s when FDI inflows surged and marked the beginning of China's ride on the wave of globalization. After it achieved unprecedented growth during the early 1990s, however, FDI inflow started to decline. This downturn continued until the next wave of FDI inflow hit China in 2000. Despite the widespread decline in global FDI inflow between 2000 and 2002, China was able to increase FDI inflow with expectations of further deregulation and China's accession to the WTO. In 2008, the value of inward FDI to China continue to increase despite financial crisis. The total value of in 2008 was 55 times larger than in 1985, accounting for 6.1 percent of global FDI inflow and almost 52 percent of aggregate FDI inflow to East Asia. However, even China was not spared a negative impact of 
the global financial crisis in 2009.

ASEAN 5 experienced a significant increase in FDI inflow during the early 1990s, accounting for 7.4 per cent of global FDI inflow in 1995. The Asian financial crisis in 1997 triggered a sharp decline in the region's FDI inflow, although individual national performances varied greatly. In order to attract further FDI inflows, the ASEAN Investment Area was established in 1998 and required the member countries to reduce or eliminate investment regulations and conditions that might impede investment flows. This provided a new impetus for economic integration among ASEAN member countries. The ASEAN Free Trade Area (AFTA) became fully operational on 1 January 2003 and this added momentum to economic integration in the region. FDI inflows to the ASEAN 5 continued to increase until 2007 reaching US\$ 65 billion.

Among the ASEAN 5, Singapore has been a leader in attracting FDI, which has played a pivotal role in that country's economy. A liberal open-door policy and extensive FDI promotion policies towards foreign investors attracted a massive amount of FDI. In 2007, Singapore retained its position as third-largest recipient in East Asia, attracting US\$ 35 billion, which accounted for approximately 55\% of total FDI inflows to the ASEAN 5. FDI inflows into the ASEAN 5 in 2008 varied significantly; they surged in Indonesia; dropped slightly in Thailand and Malaysia; and fell sharply in the Philippines and Singapore. Although inward FDI bounced in Singapore and the Philippines in 2009, it continued to decline in Thailand, Malaysia and Indonesia.

FDI inflows to the East Asian "Tigers" (Hong Kong, China, China, the Republic of Korea and Taiwan Province of China) began to increase rapidly in the early 1990s against the backdrop of strong economic growth and the liberalization of investment regimes. The slowdown of the domestic economy and the regional economic situation as a result of the Asian financial crisis prompted the sharp decline of FDI inflows to Taiwan in 1998. As a result, the share of the East Asian "Tigers" in global FDI declined to 2.8\% during the year. Since then, the share of these economies has quickly picked up and has reached at $5.4 \%$ in 2000 . Their share in global FDI inflow peaked at $6.1 \%$ in 2004.

Hong Kong experienced an unprecedented FDI boom in 1999 after it recovered from the turmoil of the Asian financial crisis. The surge reflected Hong Kong as a financial hub for business in the region, particularly in China. Hong Kong is by far the largest investor in China, and its investments have increased dramatically since early 1980s. A significant portion of the investment originates from China itself. Much of China's capital outflow that takes place either through legal or illegal channels to Chinese firms located in Hong Kong finds its way back to China as FDI. This type of "round tripping" of funds is mostly used to escape regulations such as barriers to trade or to gain eligibility for incentives available only to foreign investors e.g., tax concessions. Hong Kong is also used as a stepping stone for investment to China. A large number of foreign firms use affiliates in Hong Kong to invest in China on their behalf. In addition, many overseas companies have regional offices as well as regional headquarters in Hong Kong. It has been experiencing another surge in FDI inflows during recent years. This 
partly reflects the Closer Economic Partnership Arrangement (CEPA) signed between Hong Kong, China and China, which opened up new opportunities not only for firms in Hong Kong, China but also for foreign investors. In 2004, Hong Kong attracted almost 26\% of the FDI inflow into the region, accounting for $4.8 \%$ of global FDI inflow. Hong Kong remained as Asia's second largest destination for FDI in recent years.

Since the 1997 Asian financial crisis, the Republic of Korea has adopted extensive policy reforms in favor of FDI such as simplifying the approval procedure, the removal of various restrictions on foreign ownership, strengthening tax incentive systems and financial support for foreign investors, among others. As a result, FDI inflows began to surge in 1997 and maintained strong growth until 2000. In 2004, the inflows picked up once again and the Republic of Korea absorbed more than $1 \%$ of global FDI inflow. Inflows to Republic of Korea declined considerably in 2006 mainly due to a significant fall in the value of cross-border M\&As and divestment by foreign investors (UNCTAD 2007). Following a continuous decline in FDI inflows over the period of 2005 2007, FDI in Republic of Korea surged again despite the impact of the global financial crisis.

The inflow of FDI to Taiwan grew rapidly, particularly towards the end of the 1990s, due to a large-scale reform of various laws and regulations as well as further opening up of financial sector. However, after 2001, the absolute magnitude of FDI in Taiwan has been small, which was a clear contrast to the surge in FDI inflow to the Republic of Korea. However, in 2006, Taiwan saw the highest growth rate of FDI in this region, with inflows jumping to over US\$7 billion. This was only followed by the sharp decline in inward FDI as the global financial crisis spread to East Asia in 2008 and 2009.

\section{Gravity Equation}

\section{A. Model specification}

The gravity model has been widely applied in various studies of international trade and FDI (Feenstra et al., 2001). The gravity equation in international trade using cross-country data is commonly written as:

$$
X_{i j}=f\left(G D P_{i}, G D P_{j}, F_{i j}\right)
$$

where $X_{i j}$ is the value of the trade flow of goods from country $i$ to country $j, G D P_{i}$ and $G D P_{j}$ are the GDP in country $i$ and $j$, respectively, and $F_{i j}$ is a vector of factors that influence trade flow. The factors commonly used include the physical distance between the two countries $i$ and $j$, which is used as a proxy for transportation costs, a dummy variable that assumes the value 1 
if $i$ and $j$ share a common language and 0 otherwise, a binary variable assuming the value 1 if $i$ and $j$ share a common land border and 0 otherwise, and a dummy variable assuming the value 1 if $i$ and $j$ have a free trade agreement and 0 otherwise.

The model specification is augmented in order to examine the economic impact of FDI inflow on the host country's trade. China, Hong Kong, China, Singapore, the Republic of Korea, Thailand, Malaysia, the Philippines, Indonesia and Japan are included in the estimation for 1998 2006. Originally, the analysis was conducted using the data set between 1998 and 2009. However, the results were drastically different from what we present below. We conjecture that this paradox is due to the transient abnormality in the FDI as well as international trade data stemming from the global financial crisis of late 2000's. Therefore, we excluded the period 2007, 2008 and 2009 from our analysis.

Of particular interest is the impact of FDI on the various forms of trade in East Asia. One possible specification issue for including FDI in the gravity analysis is the endogeneity problem. More specifically, the causal relationship between FDI and trade may be driven by unobserved common factors such as variations in government policy, technology, tastes, etc. The strategy adopted here to deal with this issue is to estimate FDI at the first stage using various instrumental variables while in the second stage, bilateral trade is regressed on the predicted value of FDI as the additional independent variable. The error term in the FDI equation is, thus, uncorrelated with the error term in the trade equation.

The model predicts that FDI flow and bilateral trade flows between any two countries as:

$$
\begin{aligned}
& F D I_{i}=\alpha_{0}+\beta_{1} D_{I F P G D P}+\beta_{2} D I F W A G E_{i j}+\beta_{3} D_{U T T Y_{i}}+\beta_{4} C T A X_{i}+\beta_{5} C O R R U P T_{i} \\
& +\beta_{6} G S T A B_{i}+\beta_{7} L A W_{i}+\beta_{8} T E L_{i}+\varepsilon_{i j} \\
& T_{i j}=\gamma_{0}+\rho_{1} G D P_{i}+\rho_{2} G D P_{j}+\rho_{3} D I S T_{i j}+\rho_{4} D M B_{i}+\rho_{5} F D I+\delta_{i j}
\end{aligned}
$$

where subscripts $i$ and $j$ refer to reporting country and partner country. The definition of the variables in the above equation is listed below. Annual data for eight countries from 1998 to 2004 are used in the estimation. Equation (3) is run on parts and components and capital goods separately. In addition, the impact of an each explanatory variable on bilateral import flows and export flows are examined separately.

- $F D I_{i}$ - the level of FDI stock in reporting country.

- DIFPGDP $P_{i j}$ - the absolute value of the difference in per capita GDP between $i$ and $j$.

- $D I F W A G E_{i j}$ - the absolute value of the difference in wages between $i$ and $j$.

- DUTYi-import tariff of the host country.

- $C T A X_{I}$ - corporate tax rate of the host country.

- CORRUPT $T_{i}$ - an index of corruption in the host country.

- $G S T A B_{i}$ - an index of government stability in the host country.

- $L A W_{i}-$ an index of rule of law in the host country. 
- $T E L_{i}$ - the number of telephone main lines per 1,000 people in the host country.

- $D I S T_{i j}$ - the geographical distance between the two most important cities in $i$ and $j$.

- $T_{i j}$ - the volume of exports or imports by country $i$ to or from $j$ in total trade, intermediate or final products.

- $G D P$ - gross domestic product.

- $D M B_{i j}-$ a dummy variable that is 1 if $i$ and $j$ share a common border and 0 otherwise.

The independent variables included in equation (2) are believed to exert an influence on inward foreign direct investment in each country of East Asia by changing the investment environment through institutional and policy changes, and economic fundamentals.

Two variables have been incorporated in this analysis that may influence the level of foreign production - the absolute difference of per capita GDP (DIFPGDP) and wages (DIFWAGE). The gap in per capita GDP and wages between a reporting country and a partner country should have a positive influence on FDI with the vertical type. ${ }^{3}$ Trade in intermediate goods can be very sensitive to cost differences between two countries. For production fragmentation to take place, additional coordination costs must be offset by a reduction in the total production costs. Factor price differentials between countries allow at least one fragment to be produced more cheaply in another country (Deardorff, 2001).

Policy-related variables, such as import duty and corporate tax rates have also been incorporated. MNEs, which set up vertical production networks, may be encouraged to invest in a country with relatively low tariff barriers due to lower costs of their imported intermediate products.

Another policy-related variable that can influence a host country's location advantage is the host country's corporate or other tax rates. As global profit maximizers, MNEs can be sensitive to tax factors, since such factors have a direct effect on their profits. Evidence of significant negative influence from corporate tax rates on FDI have been reported in previous studies by Wei (1997), Gastanaga and others (1998), and Hsiao (2001).

Also included in equation (2) are institutional factors, such as the level of corruption, the stability of each government, and the rule of law. Hines (1995) showed that FDI from the United States grew more rapidly in less corrupt countries than in more corrupt countries after 1977. Wei (1997) presented an alternative explanation of the negative and significant effect of corruption on FDI. Unlike taxes, corruption is not transparent and involves many factors that are more arbitrary in nature. An agreement between a briber and a corrupt official is difficult to enforce and it creates more uncertainty over the total questionable payments or the final outcome. Wei (1997) demonstrated the fact that this type of uncertainty induced by corruption leads to a reduction in FDI. Political stability of a government and the sound rule of law can also be important factors in the inflow of FDI. Their related risks can impede FDI inflows despite favorable economic conditions.

\footnotetext{
${ }^{3}$ For a very interesting study on how vertical intra-industry trade helps integrate East Asia, see Wakasugi (2007).
} 
The last variable, TEL, included in equation (2) is a proxy for quality of infrastructure.

We now turn to equation (3). The volume of trade in both intermediate and final products is expected to be positively related the market size of the two countries concerned. The variable GDP captures the idea that larger countries trade more than small countries as they need to offer more differentiated products to satisfy a wide variety of consumers. According to the theory of fragmentation outlined by Jones and others (2004), scale of production would determine the division of labor since specialization increases as the scale of production rises. As Grossman and Helpman (2005) proposed, the variable can also be treated as a proxy for the "thickness" of the markets; this has a positive impact on the location of outsourcing, as the likelihood of the firms finding an appropriate partner in their search increases as the size of a country increases.

The distance variable is considered to be a crucial factor in explaining international trade since distance increases transportation costs, which is a trade-resistance factor that negatively influences the bilateral trade volume. In particular, transportation costs are considered to have a larger impact on decisions concerning production fragmentation, as each intermediate product that belongs to the same value-added chain may cross national boarder multiple times.

The final variable is a dummy variable with regard to whether the importing country and exporting country are adjacent. The dummy variables may capture various factors that lead to reduced business transaction costs. For example, firms in adjacent countries are likely to have a better understanding of business practices than firms from a different business environment. This familiarity certainly helps to reduce the cost involving uncertainty. The familiarity with the business environment also helps to reduce the difficulty of finding an appropriate outsourcing partner in production networks. Except for the dummies, all variables are log-linearized. Sources for the variables are listed in Appendix 2.

\section{B. Empirical results}

Table 5 presents the estimation results using random effect model. It reveals a positive and statistically significant influence of all countries' direct investment on trade in parts and components as well as in capital goods. The results indicate that FDI by all source countries is positively related to both intra-regional bilateral exports and imports of parts and components as well as capital goods. Thus inward FDI and trade in both parts and components and capital goods are complementary. On the import side, the result may be attributed to various trade liberalization policies and institutional changes that many East Asian economies pursued during the 1990s to help generate greater openness for trade. For example, many East Asian economies unilaterally eliminated their tariffs on capital and intermediate goods. In addition, duties on trade in information technology products were completely eliminated due to the completion of the Information Technology Agreement (ITA) in 1996. This is important because among the commodities actively traded in the East Asian region (excluding Japan) the leading category is 
information technology products. Regarding institutional changes, the establishment of Export Processing Zones (EPZs), where manufacturers can enjoy import duty exemption as well as extensive usage of a duty drawback system on the imported parts and components used for the production of exports, effectively reduces the impact of tariff barriers.

Table 5. Regression results

\begin{tabular}{|c|c|c|c|c|c|c|}
\hline \multirow{3}{*}{$\begin{array}{c}\text { Explanatory } \\
\text { Variables }\end{array}$} & \multicolumn{6}{|c|}{ Dependent Variable : Export } \\
\hline & \multicolumn{2}{|c|}{ FDI from Japan } & \multicolumn{2}{|c|}{ FDI from Germany } & \multicolumn{2}{|c|}{ FDI from France } \\
\hline & PC & $\mathrm{CA}$ & PC & $\mathrm{CA}$ & $\mathrm{PC}$ & $\mathrm{CA}$ \\
\hline$G D P$, reporter & $\begin{array}{c}0.671 * * * \\
(0.062)\end{array}$ & $\begin{array}{c}0.728 * * * \\
(0.063)\end{array}$ & $\begin{array}{c}0.487 * * * \\
(0.074)\end{array}$ & $\begin{array}{c}0.686^{* * * *} \\
(0.077)\end{array}$ & $\begin{array}{c}0.470 * * * \\
(0.065)\end{array}$ & $\begin{array}{c}0.647 * * * \\
(0.070)\end{array}$ \\
\hline GDP, partner & $\begin{array}{c}0.726 * * * \\
(0.057)\end{array}$ & $\begin{array}{c}0.691 * * * \\
(0.058)\end{array}$ & $\begin{array}{c}0.770 * * * \\
(0.055)\end{array}$ & $\begin{array}{c}0.781 * * * \\
(0.057)\end{array}$ & $\begin{array}{c}0.654 * * * \\
(0.055)\end{array}$ & $\begin{array}{c}0.683 * * * \\
(0.058)\end{array}$ \\
\hline DIST & $\begin{array}{c}-1.174 * * * \\
(0.210)\end{array}$ & $\begin{array}{c}-0.935 * * * \\
(0.187)\end{array}$ & $\begin{array}{c}-1.137 * * * \\
(0.204)\end{array}$ & $\begin{array}{c}-0.988 * * * \\
(0.187)\end{array}$ & $\begin{array}{c}-1.055^{* * * *} \\
(0.195)\end{array}$ & $\begin{array}{c}-0.903 * * * \\
(0.185)\end{array}$ \\
\hline$D B$ & $\begin{array}{l}-0.141 \\
(0.382)\end{array}$ & $\begin{array}{c}0.291 \\
(0.339)\end{array}$ & $\begin{array}{l}-0.100 \\
(0.371)\end{array}$ & $\begin{array}{c}0.240 \\
(0.338)\end{array}$ & $\begin{array}{c}-0.007 \\
(0.355)\end{array}$ & $\begin{array}{c}0.347 \\
(0.344)\end{array}$ \\
\hline $\begin{array}{l}\text { FDI } \\
\text {-predicted }\end{array}$ & $\begin{array}{c}0.666 * * * \\
(0.106)\end{array}$ & $\begin{array}{c}1.129 * * * \\
(0.119)\end{array}$ & $\begin{array}{c}0.422 * * * \\
(0.058)\end{array}$ & $\begin{array}{c}0.405 * * * \\
(0.067)\end{array}$ & $\begin{array}{c}0.471 * * * \\
(0.049)\end{array}$ & $\begin{array}{c}0.481 * * * \\
(0.057)\end{array}$ \\
\hline $\begin{array}{l}\text { LM } \\
\text { observations }\end{array}$ & $\begin{array}{l}1 \% \\
643\end{array}$ & $\begin{array}{l}1 \% \\
643\end{array}$ & $\begin{array}{l}1 \% \\
643\end{array}$ & $\begin{array}{l}1 \% \\
643\end{array}$ & $\begin{array}{l}1 \% \\
643\end{array}$ & $\begin{array}{l}1 \% \\
643\end{array}$ \\
\hline \multirow{3}{*}{$\begin{array}{c}\text { Explanatory } \\
\text { Variables }\end{array}$} & \multicolumn{6}{|c|}{ Dependent Variable : Import } \\
\hline & \multicolumn{2}{|c|}{ FDI from Japan } & \multicolumn{2}{|c|}{ FDI from Germany } & \multicolumn{2}{|c|}{ FDI from France } \\
\hline & $\mathrm{PC}$ & CA & $\mathrm{PC}$ & CA & $\mathrm{PC}$ & CA \\
\hline$G D P$, reporter & $\begin{array}{c}0.593 * * * \\
(0.066)\end{array}$ & $\begin{array}{c}0.671 * * * \\
(0.064)\end{array}$ & $\begin{array}{c}0.328 * * * \\
(0.075)\end{array}$ & $\begin{array}{c}0.450^{* * *} \\
(0.076)\end{array}$ & $\begin{array}{c}0.428^{* * *} \\
(0.069)\end{array}$ & $\begin{array}{c}0.597 * * * \\
(0.071)\end{array}$ \\
\hline GDP, partner & $\begin{array}{c}0.858 * * * \\
(0.060)\end{array}$ & $\begin{array}{c}0.805^{* * *} \\
(0.059)\end{array}$ & $\begin{array}{c}0.896^{* * * *} \\
(0.055)\end{array}$ & $\begin{array}{c}0.854 * * * \\
(0.056)\end{array}$ & $\begin{array}{c}0.810^{* * *} \\
(0.581)\end{array}$ & $\begin{array}{c}0.802 * * * \\
(0.059)\end{array}$ \\
\hline DIST & $\begin{array}{c}-1.059 * * * \\
(0.239)\end{array}$ & $\begin{array}{c}-0.797 \\
(0.194)\end{array}$ & $\begin{array}{c}-0.987 * * * \\
(0.214)\end{array}$ & $\begin{array}{c}-0.754 * * * \\
(0.186)\end{array}$ & $\begin{array}{c}-0.967 * * * \\
(0.223)\end{array}$ & $\begin{array}{c}-0.769 * * * \\
(0.192)\end{array}$ \\
\hline$D B$ & $\begin{array}{l}-0.195 \\
(0.435)\end{array}$ & $\begin{array}{c}0.201 \\
(0.352)\end{array}$ & $\begin{array}{l}-0.125 \\
(0.389)\end{array}$ & $\begin{array}{c}0.245 \\
(0.336)\end{array}$ & $\begin{array}{c}-0.091 \\
(0.405)\end{array}$ & $\begin{array}{c}0.248 \\
(0.346)\end{array}$ \\
\hline $\begin{array}{l}\text { FDI } \\
\text {-predicted }\end{array}$ & $\begin{array}{c}0.668 * * * \\
(0.107)\end{array}$ & $\begin{array}{c}0.880 * * * \\
(0.121)\end{array}$ & $\begin{array}{c}0.449 * * * \\
(0.058)\end{array}$ & $\begin{array}{c}0.539 * * * \\
(0.066)\end{array}$ & $\begin{array}{c}0.416^{* * *} \\
(0.049)\end{array}$ & $\begin{array}{c}0.381 * * * \\
(0.057)\end{array}$ \\
\hline $\begin{array}{l}\text { LM } \\
\text { observations }\end{array}$ & $\begin{array}{l}1 \% \\
643\end{array}$ & $\begin{array}{l}1 \% \\
643\end{array}$ & $\begin{array}{l}1 \% \\
643\end{array}$ & $\begin{array}{l}1 \% \\
643\end{array}$ & $\begin{array}{l}1 \% \\
643\end{array}$ & $\begin{array}{l}1 \% \\
643\end{array}$ \\
\hline
\end{tabular}

(Note) PC: parts and components CA: capital goods, standard error in parenthesis 
As discussed in Section I, Antras (2005) provides a theoretical framework of the various stages of offshoring or international production fragmentation. Stage I consists of firms producing parts within the home countries. Stage II refers to the situation when the firms invest abroad and the affiliates source their more standardized parts from developing countries. This is the stage when FDI plays an important role. At Stage III, the multinational firms procure from the localized firms and leave much of the production chain to the developing countries. The set of variables that affect the progression of the stages include the quality of the institutions in the developing countries, the relative wages as well as the degree of standardization of the parts. Using Antras' basic taxonomy, East Asia remains at Stage II of the product cycle in offshoring.

Furthermore, a closer look reveals that the magnitude of the coefficient of parts and components is far from homogenous among the source countries. Japanese direct investment appears to have a very large effect on both intra-East Asian bilateral exports and imports relative to FDI from France and Germany.

Japanese manufacturing industries concentrated their business networks in East Asia in order to achieve the economies of scale. During the process, a cross-border division of labor by Japanese MNEs started to expand from between Japan and East Asia to between the East Asian countries not including Japan (METI 2008). The large impact of Japanese direct investment on the intra-regional trade of parts and components may be attributed to this distinctive characteristic of Japanese direct investment.

Regarding intra-regional bilateral exports and imports of capital goods, the difference in the magnitude of the impact of Japanese direct investment relative to other FDI source countries is magnified in both exports and imports. The stark difference can partly be due to an extensiveness of Japanese machinery production in Asia and the fact that a wide range of goods that can be used as intermediate inputs in related industries being classified as "Capital Goods" in the BEC as we discussed in previous section.

In $2003,18 \%$ of general machinery industry affiliates were located in China, $16 \%$ in North America, $15 \%$ in ASEAN and $8 \%$ in the NIEs economies (JBIC, 2004). Furthermore, with the assistance of the Keiretsu system and the assistance of local Japanese government in deploying overseas operation for SMEs, very strong intra- and inter- industry relationships exists. Over time, these working and sometimes personal relationships of "fellow Japanese" developed into a valuable trust that allows further intra and inter industrial co-operations that otherwise would not have existed.

Another key aspect of Japanese machinery industries is that they possess leading technology and organization in the post WWII period. Japan was the early adaptors and developers of Numeric Control technology (NC), which they aggressively applied to their products with continual improvements. This effort resulted in high valuation and world wide acceptance of their machineries in the latter half of 1970s. In 1982, Japan has become the world's largest machine tool producer of the world. At their peak production in 1990, Japan recorded a value 
of US\$13 billion. Since then, Japan has continued to lead the industry.

Japanese manufacturing industry as a whole, has also produced more and more varieties of output. Ranging from relatively low-tech components, to high-tech machineries like to aerospace components. In contrast, it seems that the French and German industries produce narrower selections.

A large impact of Japanese direct investment on the bilateral intra-regional trade in Asia can be best understood by the wide range of offerings from Japan and from their affiliates in Asia, many of which fall into the "Capital Goods" classification. The overall results are consistent with the hypothesis. The relatively large impact of the distance variable found in this study implies that high potential benefits for East Asian countries that could be materialized by reducing the of trade costs. The adjacency dummy is not found to have significant influence on regional bilateral trade.

\section{Conclusion}

Our paper highlights the importance of FDI in general and Japanese FDI in particular in facilitating trade in parts and components. This corresponds to stage II of Antra's theory. In stage III, domestic suppliers from East and Southeast Asia will step in and take control of such form of trade and production integration. We document the growing importance of intra-East Asian trade of parts and components. Our statistical analysis based on the gravity model shows that FDI from Japan, Germany and France all play an important role in facilitating the trade of parts and components in East Asia. Using Antras' basic taxonomy, East Asia remains at Stage II of the product cycle in offshoring. Furthermore, if we adopt Antras' framework, this implies that institutional quality, particularly intellectual property rights protection, remains a concern for the decision to localize the production chain in the host economies.

Does the source of FDI matter for the linkages between FDI and the various modes of trade? Our empirical studies show that FDI from Japan has a particularly strong influence on both trade in parts and components as well as trade in capital goods compared to the case of FDI from France and Germany. With respect to capital goods, it is fairly well-known that the Japanese engineering and machinery sector has a distinguished history and continues to be a leading sector of the economy. It seems likely that Japanese affiliates are set up abroad to import machinery from Japan or to manufacture and export some of the capital goods to other Asian economies. Such capital goods are used to produce and then export parts and components. Thus, trade in capital goods and trade in parts are both facilitated by Japanese direct investment and the two modes of trade are positively correlated. In addition, FDI rather than local supply is needed both because of the quality of the machinery as well as the importance of safeguarding the intellectual content of such capital goods. Other complementary 
explanations of the significant influence of Japanese FDI on modes of intra-East Asian trade include the activities of the small and medium enterprises as well as other keiretsu suppliers that follow the Japanese multinationals when they go abroad. In contrast, direct investments from France and Germany also facilitate trade in parts and components as well as capital goods. Without the keiretsu linkages, the European firms may use more local suppliers as well as supplies from other foreign affiliates in the region.

The fact that German and French FDI seem to contribute less to trade in parts and components in East and Southeast Asia may reflect that such trade that is associated with these European companies involve other entities such as local suppliers and/or affiliates of other multinationals.

Received 20 December 2012, Revised 6 April 2013, Accepted 9 May 2013

\section{References}

Antras, Pol, 2005, "Incomplete contracts and the product cycle," American Economic Review, vol. 95, No.4, pp. 1054-1073.

Athukorala, P. C., 2006. "Product fragmentation and trade patterns in East Asia", Asian Economic Papers, vol. 4, No. 3; pp. 1-27.

Borrus, Michael, 1997, "Left for dead: Asian production networks and the revival of US electronics", in B. Naughton (eds.), The China Circle Economics and Technology in the PRC, Taiwan, and Hong Kong, Washington, DC: Brookings Institution Press, pp.139-163.

Borrus, M., D. Ernst and S. Haggard, 2000, "Introduction: cross-border production networks and the industrial integration of the Asia-Pacific region" in M. Borrus, D. Ernst and S. Haggard (eds.), International Production Networks in Asia: Rivalry or riches?, pp4-29. Routledge.

Deardorff, A. V., 2001. "Fragmentation across cones", in S. W. Arndt and H. Kierzkowski (eds.), Fragmentation: New Production Patterns in the World Economy, pp. 35-51. Oxford University Press.

Ernst, Dieter, 2000. "Evolutionary Aspects: the Asian production networks of Japanese electronics firms", in M. Borrus, D. Ernst and S. Haggard (eds.), International Production Networks in Asia: Rivalry or riches?, pp79-107. Routledge.

Farrell, Roger Simon, 2008. Japanese Investment in the World Economy: A Study of Strategic Themes in the Internationalization of Japanese Industry, Edward Elgar Publishing.

Feenstra, Robert C., James R. Markusen and Andrew K. Rose, 2001, "Using the gravity equation to differentiate among alternative theories of trade", Canadian Journal of Economics, 34 (2), 430-437.

Fung, K.C., 2002, "International Trade and Bank Groups: Welfare Enhancing or Welfare Reducing?" Journal of the Japanese and International Economies, 16, 212-226.

Fung, K.C., Alicia Garcia-Herrero and Alan Siu, 2009, "Production Sharing in Latin America and East Asia," in Sino-Latin American Economic Relation, eds. K.C. Fung and Alicia Garcia-Herrero, Routledge Press, forthcoming. 
Fung, K.C., Hitomi Iizaka and Alan Siu, 2010, "U.S., Japanese and Korean FDI and Intra-Regional East Asian Trade," Asian Economic Papers, forthcoming.

Gastanaga, V. M., J. B. Nugent and B. Pashamova, 1998. "Host country reforms and FDI inflows: How much difference do they make?" World Development, vol. 26, No. 7; pp. 1299-1314.

Gereffi, G., Humphrey, J. and Sturgeon, T., 2005, "The Governance of Global ValueChains", Review of International Political Economy, 12 (1), pp.78-104.

Grossman, G. M. and E. Helpman, 2005. "Outsourcing in a global economy", Review of Economic Studies, vol. 72, No. 1; pp. 135-159.

Hanson, G. H., R. J. Mataloni, Jr., and M. J. Slaughter, 2001. "Expansion strategies of U.S. multinational firms", in S. M. Collins and D. Rodrik (eds.), Brookings Trade Forum 2001, pp. 245-282. Washington, D.C., Brookings Institution Press.

Hines, J. R., Jr., 1995. “Forbidden payment: Foreign bribery and American business after 1977”, National Bureau of Economic Research working paper, No. 5266. Cambridge, MA, United States.

Hiratsuka, Daisuke, 2008. “Japan's Outward FDI in the Era of Globalization”, in R. S. Rajan, R. Kumar and N. Virgill (eds.), New Dimensions of Economic Globalization: Surge of Outward Foreign Direct Investment from Asia, pp. 87-114. World Scientific Publishing Company, Incorporated.

Hsiao, C., 2001. "Efficient estimation of dynamic panel data models - with an application to the analysis of foreign direct investment to developing countries," paper prepared for the 2001 Econometric Society Far Eastern Meeting in Kobe, Japan.

Hummels, D., J. Ishii and K-M Yi, 2001. "The nature and growth of vertical specialization in world trade", Journal of International Economics, vol. 54, No. 1; pp. 75-96.

Japanese Bank of International Cooperation, 2004. JBIC Review, May, Tokyo

Jones, R. W., and H. Kierzkowski, 1990. "The role of services in production and international trade: A theoretical framework," in R. Jones and A. Krueger (eds.), The Political Economy of International Trade: Festschrift in honor of Robert Baldwin, pp. 31-48. Oxford, Basil Blackwell.

Jones, R. W., H. Kierzkowski and C. Lurong, 2004. "What does the evidence tell us about fragmentation and outsourcing", International Review of Economics and Finance, vol. 14, No. 3; pp. 305-316.

Krugman, P., 1995. "Growing world trade: Causes and consequences", Brooking Papers on Economic Activity 1; pp. 327-377.

White Paper on International Economy and Trade 2008, Ministry of Economy, Trade and Industry, Japan.

Ng, F. and A. Yeats, 2003. "Major trade trends in East Asia: What are their implications for regional cooperation and growth?", policy research working paper No. 3084, World Bank, Washington, D.C.

— 2001. "Production sharing in East Asia: Who does what for whom, and why?" in L. K. Cheng and H. Kierzkowski (eds.), Global Production and Trade in East Asia, pp. 63-109. Boston, Kluwer Academic.

Sturgeon, T.J., 2003, "What really goes on in Silicon Valley? Spatial clustering and dispersal in modular production networks", Journal of Economic Geography, 3, pp.199-225.

Wakasugi, Ryuhei, 2007, "Vertical Intra-Industry Trade and Economic Integration in East Asia," Asian Economic Papers, Winter, v.6, No.1, pp.26-39.

Wei, S-J., 1997. "Why is corruption so much more taxing than tax? Arbitrariness kills", National Bureau of 
Economic Research working paper, No. 6255. Cambridge, MA, United States.

Zhang, Zhaoyong, 2010, "Trade Liberalization, Economic Growth and Convergence: Evidence From East Asian Economies", Journal of Economic Integration, National University of Singapore. 


\section{Appendix 1. Commodity Code}

\begin{tabular}{|c|c|}
\hline Code & Explanation \\
\hline 1 & Food and beverages \\
\hline 11 & Food and beverages, primary \\
\hline 111 & Food and beverages, primary, mainly for industry $(\mathrm{P})$ \\
\hline 112 & Food and beverages, primary, mainly for household consumption (F-C) \\
\hline 12 & Food and beverages, processed \\
\hline 121 & Food and beverages, processed, mainly for industry (IM-SF) \\
\hline 122 & Food and beverages, processed, mainly for household consumption (F-C) \\
\hline 2 & Industrial supplies nes \\
\hline 21 & Industrial supplies nes, primary $(\mathrm{P})$ \\
\hline 22 & Industrial supplies new, processed (IM-SF) \\
\hline 3 & Fuels and lubricants \\
\hline 31 & Fuels and lubricants, primary $(\mathrm{P})$ \\
\hline 32 & Fuels and lubricants, processed \\
\hline 321 & Fuels and lubricants, processed, motor spirit \\
\hline 322 & Fuels and lubricants, processed (other than motor spirit) (IM-SF) \\
\hline 4 & Capital goods (except transport equipment), and parts and accessories thereof \\
\hline 41 & Capital goods (except transport equipment) (F-CA) \\
\hline 42 & Parts and accessories of capital goods (except transport equipment) (IM-PC) \\
\hline 5 & Transport equipment, and parts and accessories thereof \\
\hline 51 & Transport equipment, passenger motor cars (F-C) \\
\hline 52 & Transport equipment, other \\
\hline 521 & Transport equipment, other, industrial (F-CA) \\
\hline 522 & Transport equipment, other, non-industrial (F-C) \\
\hline 53 & Parts and accessories of transport equipment (IM-PC) \\
\hline 6 & Consumption gods nes \\
\hline 61 & Consumption goods nes, durable (F-C) \\
\hline 62 & Consumption goods nes, semi-durable (F-C) \\
\hline 63 & Consumption goods nes, non-durable (F-C) \\
\hline 7 & Goods nes \\
\hline
\end{tabular}

(Note) P: Primary goods

IM-SF: Semi-finished goods under Intermediate goods

IM-PC: Parts \& components under Intermediate goods

F-CA: Capital goods under Final goods

F-C: Consumption goods under Final goods

321 and 7 are treated as "others" 


\section{Appendix 2. Source of variables}

\begin{tabular}{|c|l|}
\hline Variable & \multicolumn{1}{|c|}{ Explanation } \\
\hline FDI & $\begin{array}{l}\text { Aggregate FDI inflows of each country, aggregate FDI inflows to East Asia, and } \\
\text { aggregate FDI to the world are from UNCTAD. }\end{array}$ \\
\hline CORRUPT & $\begin{array}{l}\text { An index of corruption from the International Country Risk Guide by the PRS Group. } \\
\text { It ranges from 0 to 6, with a higher number indicating a lower level of corruption. }\end{array}$ \\
\hline GSTAB & $\begin{array}{l}\text { An index of government stability from the International Country Risk Guide by the } \\
\text { PRS Group. The range is from 0 to 12. A higher score means higher stability of a } \\
\text { government. }\end{array}$ \\
\hline Law & $\begin{array}{l}\text { An index of Law and Order from the International Country Risk Guide by the PRS } \\
\text { Group. It ranges from 0 to 6, where a higher number indicates a better system of law } \\
\text { and order. }\end{array}$ \\
\hline DUTY & $\begin{array}{l}\text { Import duties are from the International Monetary Fund's Government Finance } \\
\text { Statistic Yearbook. }\end{array}$ \\
\hline WAGE & $\begin{array}{l}\text { Average wages in manufacturing from the United Nations Common Database, } \\
\text { LABORSTA and official country websites. }\end{array}$ \\
\hline CPTAX & $\begin{array}{l}\text { Corporate income tax rate, measured in percentage points, from Worldwide Summary } \\
\text { by PricewaterhouseCoopers website. }\end{array}$ \\
\hline TEL & Telephone mainlines (per 1,000 people) from World Development Indicators. \\
\hline GDP & GDP in United States dollars are from EconStats. \\
\hline
\end{tabular}

